Maria Lima, Athina-Maria Aloizou, Vasileios Siokas, Christos Bakirtzis, Ioannis Liampas, Zisis Tsouris, Dimitrios P. Bogdanos, Stavros J. Baloyannis and Efthimios Dardiotis*

\title{
Coronaviruses and their relationship with multiple sclerosis: is the prevalence of multiple sclerosis going to increase after the Covid-19 pandemia?
}

https://doi.org/10.1515/revneuro-2021-0148

Received November 1, 2021; accepted January 24, 2022;

published online March 7, 2022

\begin{abstract}
The purpose of this review is to examine whether there is a possible (etiological/triggering) relationship between infection with various Coronaviruses, including Severe Acute Respiratory Syndrome-related Coronavirus-2 (SARS-CoV-2), the virus responsible for the Coronavirus disease-19 (Covid-19) pandemia, and Multiple Sclerosis (MS), and whether an increase of the prevalence of MS after the current Covid-19 pandemia should be expected, examining new and preexisting data. Although the exact pathogenesis of MS remains unknown, environmental agents seem to greatly influence the onset of the disease, with viruses being the most popular candidate. Existing data support this possible etiological relationship between viruses and MS, and experimental studies show that Coronaviruses can actually induce an MS-like demyelinating disease in animal models. Findings in MS patients could also be compatible with this coronaviral MS
\end{abstract}

*Corresponding author: Efthimios Dardiotis, Department of Neurology, University Hospital of Larissa, Faculty of Medicine, University of Thessaly, Biopolis, Mezourlo Hill, Larissa, 41100, Greece, E-mail: edar@med.uth.gr

Maria Lima, Athina-Maria Aloizou, Vasileios Siokas, Ioannis Liampas and Zisis Tsouris, Department of Neurology, University General Hospital of Larissa, Faculty of Medicine, School of Health Sciences, University of Thessaly, 41100, Larissa, Greece. https://orcid.org/ 0000-0002-2958-5220 (I. Liampas)

Christos Bakirtzis, B' Department of Neurology, Multiple Sclerosis Center, AHEPA University Hospital, Aristotle University of Thessaloniki, 54636, Thessaloniki, Greece

Dimitrios P. Bogdanos, Department of Rheumatology and clinical Immunology, University General Hospital of Larissa, Faculty of Medicine, School of Health Sciences, University of Thessaly, 40500 Viopolis, Larissa, Greece

Stavros J. Baloyannis, Research Institute for Alzheimer's disease, Aristotle University of Thessaloniki, 57200 Iraklio Lagkada, Thessaloniki, Greece; and 1st Department of Neurology, AHEPA University Hospital, Aristotle University of Thessaloniki, 54636, Thessaloniki, Greece hypothesis. More importantly, current data from the Covid19 pandemia show that SARS-CoV-2 can trigger autoimmunity and possibly induce autoimmune diseases, in the Central Nervous System as well, strengthening the viral hypothesis of MS. If we accept that Coronaviruses can induce MS, it is reasonable to expect an increase in the prevalence of MS after the Covid-19 pandemia. This knowledge is of great importance in order to protect the aging groups that are more vulnerable against autoimmune diseases and MS specifically, and to establish proper vaccination and health policies.

Keywords: autoimmunity; CoV-induced demyelinating disease; demyelination; MS pathogenesis; SARS-CoV-2; viral hypothesis.

\section{Introduction}

The first coronavirus (CoV), Infectious Bronchitis Virus (IBV), was isolated in the 1930s, as the etiologic agent of a highly transmittable respiratory disease in chicken (Lalchhandama 2020; Schochetman et al. 1977; Tyrrell et al. 1975), and since then, a plethora of diseases in many species of birds and mammals have been reported (Durham et al. 1979). In 1947, an apparently unrelated murine encephalomyelitis, with widespread demyelination in the central nervous system (CNS), was first described in a laboratory (Cheever and Daniels 1949). The virus causing the disease was named JHM, after Dr. John Howard Mueller (Pappenheimer 1958). It was later identified as the neurotropic strain of the Murine Hepatitis Virus (MHV), discovered years later (Herndon et al. 1975; Lalchhandama 2020), and it is the main CoV used in the animal projects in order to induce and study demyelination in the CNS. In 1960s, common cold in humans was for the first time attributed to a novel type of virus named B814 (Tyrrell and Bynoe 1965), and this was actually the first human coronavirus ( $\mathrm{HCoV}$ ) (Su et al. 2016). However, the name "coronavirus" appeared later, in 1968 
(Weiss and Navas-Martin 2005), when electron microscope studies discovered spike projections on the surface of these viruses, which resembled a crown. Crown is called corona in Latin (Lai and Cavanagh 1997), etymo-

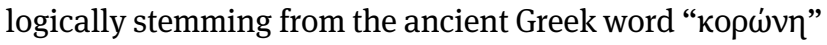
(korốnē, "garland, wreath") (https://en.wiktionary.org/ wiki/corona\#Etymology_1). There are now seven known HCoVs (Lu et al. 2020). A HCoV infection can run its course without symptoms or give way to symptoms from the respiratory, gastrointestinal and neurological systems (Paules et al. 2020). Four of these HCoVs, namely 229E, OC43, HKU1, NL63, are not regarded as highly pathogenic. Severe Acute Respiratory Syndrome-related Coronavirus (SARS-CoV) and Middle East Respiratory Syndrome-related Coronavirus (MERS-CoV) were the etiological factors of two epidemics in the past (Corman et al. 2018), while the novel Severe Acute Respiratory Syndrome-related Coronavirus-2 (SARS-CoV-2) led to the most recent, still ongoing Coronavirus disease-19 (Covid-19) pandemia (Zhu et al. 2020). All of these strands can cause acute respiratory failure and death (Rabaan et al. 2020).

Back in 1976, an autopsy of brain tissue from an active multiple sclerosis (MS) lesion, with the means of electron microscopy, discovered donut-shaped particles with a diameter of 55-65 nm, in the rough endoplasmic reticulum (RET) of the examined cells (Tanaka et al. 1976) tsf. The morphology bore a striking resemblance to $\mathrm{CoV}$, while it is now known that these viruses mature in the cisterns of the RET (Hovanec and Flanagan 1983). Toward that path, two CoVs were also later identified in brain autopsy samples from two other MS patients (Burks et al. 1980). As such, some of the first detections of CoVs in human tissues came from samples of MS patients, and this expectedly further raised the question of whether this finding was just coincidental or not, although the suspicion that CoVs may be associated to MS had already been expressed, due to their ability to induce demyelination in experimental animal models.

As it is evident, CoVs have been associated with MS even from the first years of their appearance in the foreground. Since then, a plethora of works tried to study the possible causal relationship of CoVs and MS. In the current Covid-19 pandemia, it has been shown that this novel SARS-CoV-2, like all the members of the $\mathrm{HCoV}$ family, has the ability to directly infect the CNS, inducing neurological manifestations; it is, in other words, neuroinvasive, neurotropic and neurovirulent (Lima et al. 2020). Consequently, the following "forgotten" question resurfaces again: is there a causal relationship between CoVs and demyelinating diseases, and MS in particular? In this review, we aim to answer this question, by describing and summarizing all the existing and recent data.

\section{MS pathogenesis}

The pathogenesis of MS has been studied for years, but the mechanisms responsible for the induction of the disease are not fully elucidated. A simplified schematic representation of key cells participating in the pathogenesis of MS can be seen in Figure 1, while microscopic images of pathological processes can be seen in Figures 2 and 3.

MS is characterized as a chronic, demyelinating, inflammatory and neurodegenerative disease of the CNS (Baloyannis 2020), with deficient repair mechanisms (Grigoriadis et al. 2015) and heterogenous pathogenesis, clinical course, neuroradiological findings and response to therapeutical efforts (Lucchinetti et al. 2000; Multiple sclerosis genomic map implicates peripheral immune cells and microglia in susceptibility 2019). The precise etiology of the disease is still unknown; an interaction between genetic (notably immunogenetic, such as the HLA haplotype), autoimmune and environmental factors is most likely involved (Dardiotis et al. 2017, 2019a, 2019b; Ebers and Sadovnick 1994; Hadjigeorgiou et al. 2019; Mentis et al. 2017; Sadovnick et al. 1993; Siokas et al. 2020, 2021; Sokratous et al. 2016, 2018). Among the environmental ones, viral infections are prominent participating factors (Boucher et al. 2001; Lucchinetti et al. 2000; Sospedra and Martin 2005). Overall, MS could be characterized as a disturbance of the close interplay and harmonious collaboration of CNS cells (Baloyannis and Stavros 2020), progressively leading to neural tissue destruction, more permanent symptoms and disability (Koutsouraki et al. 2010).

Animal models, especially this of experimental autoimmune encephalomyelitis (EAE), have been the main source of information on the perplexed mechanisms of relevance to the pathogenesis of MS (Rangachari and Kuchroo 2013; Strachan-Whaley et al. 2014) (Figures 2 and 3). EAE studies have long provided evidence that shows how a variety of cytokines, chemokines and adhesion molecules attract leukocytes from the periphery into the CNS, as the disrupted Blood-Brain Barrier (BBB) cannot halt their migration (Grigoriadis et al. 2006; Steinman 2001). The BBB disruption is the outcome of activated lymphocytes, aided by matrix metalloproteases (MMPs), like gelatinase B, which 


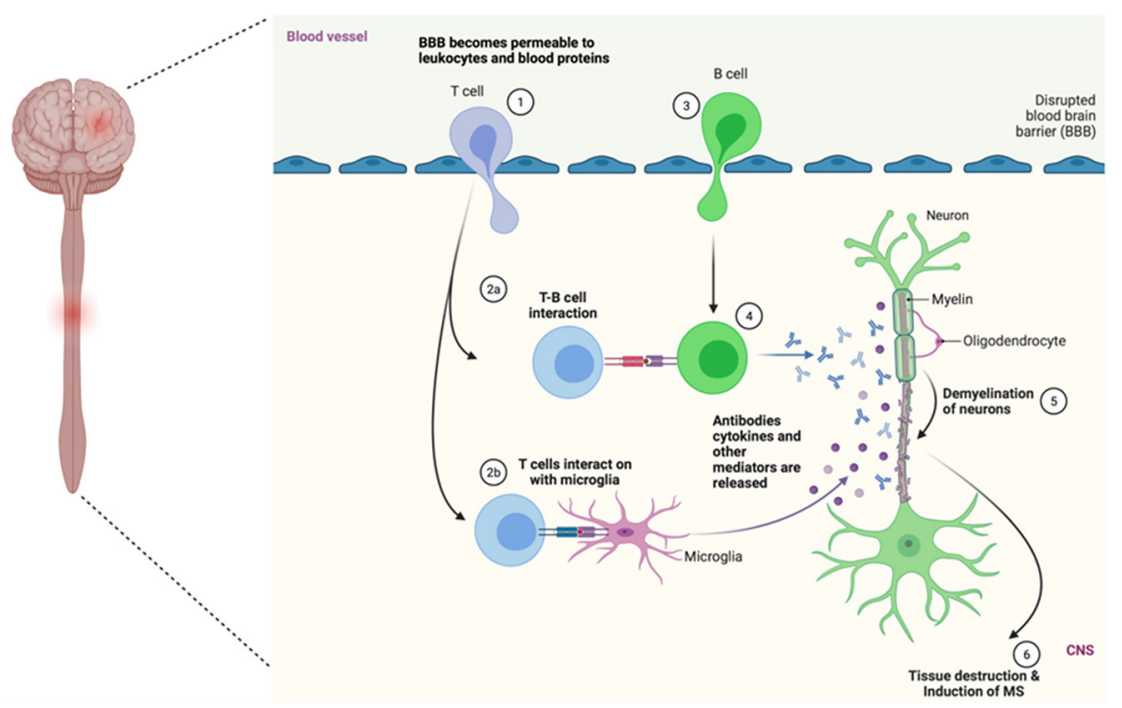

Figure 1: Pathogenesis of multiple sclerosis. The figure was prepared using the BioRender platform (under license to DPB). are also detectable in the cerebrospinal fluid (CSF) of MS patients, and in endothelial cells, pericytes, macrophages and astrocytes of lesions (Conlon et al. 1999). Once the BBB has been compromised, pro-inflammatory cells, uninhibited, penetrate into the CNS and reacting to CNS antigens and coming in contact with antigen-presenting cells (APCs), are locally re-activated and induce an inflammatory response (Compston and Coles 2008; Hemmer et al. 2006; Sospedra and Martin 2005).

Memory $\mathrm{T}$ cells are peripherally activated (Hemmer et al. 2006) and their activation is thought to be mediated by interactions between genetic and environmental factors (Sospedra and Martin 2005). These T cells target certain proteins that are physiologically located in the myelin

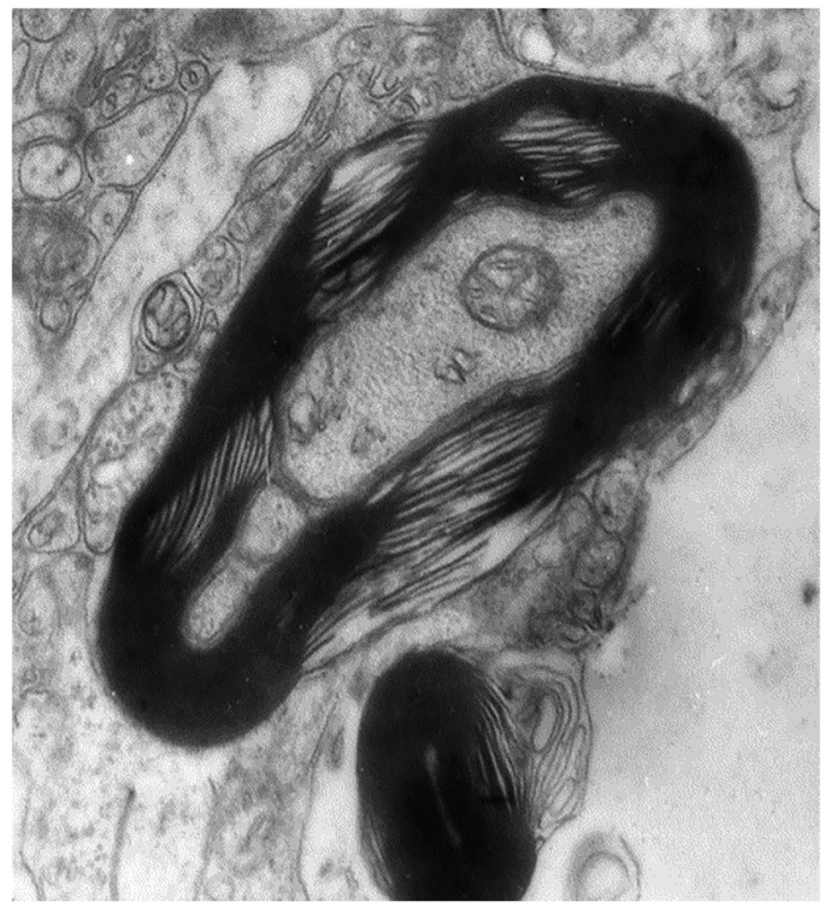

Figure 2: Separation of the lamellae of the myelin sheath in a Purkinje cell axon at the initial stage of demyelination. Electron micrograph, original magnification: 25.000x. From EAE in Lewis rats (IgB1). Ultrastructural analysis was performed on two electron microscopes, namely (A) a Siemens Elmiscope I and (B) a Carl Zeiss 9As. Courtesy of Prof. em. Stavros J. Baloyannis.

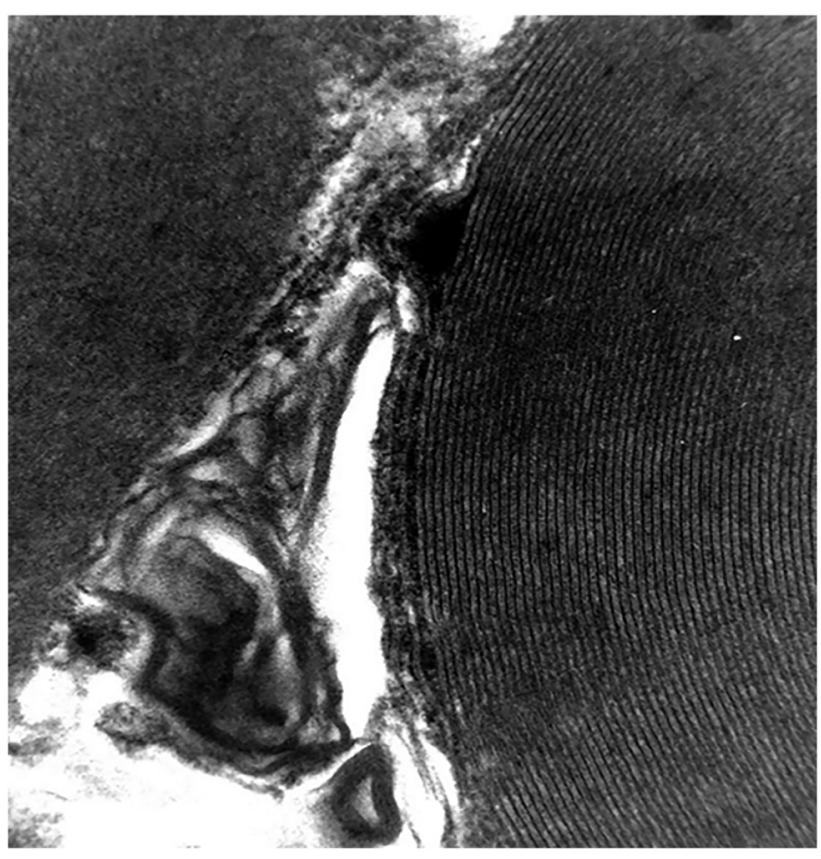

Figure 3: Fragmentation of the myelin sheath of a heavy myelinated axon at the initial stages of demyelination.

The demyelination started in the Schmidt-Lanterman incisures. Electron micrograph, origianl magnification: 250.000x. From EAE in Lewis rats (IgB1). Ultrastructural analysis was performed on two electron microscopes, namely (A) a Siemens Elmiscope I and (B) a Carl Zeiss 9As. Courtesy of Prof. em. Stavros J. Baloyannis. 
sheath of neurons, and produce cytokines that lead macrophages, microglial cells and astrocytes to further secrete other pro-inflammatory mediators, such as oxygen and nitric oxide radicals (NO), and osteopontin (OPN). This inflammatory cascade drives microglia into attacking oligodendroglial cells and leading consequently to myelin disintegration and axonal damage (Figure 1) (Kawanokuchi et al. 2008; Murphy et al. 2010). Additionally, excessive release of glutamate from lymphocytes, astrocytes, pericytes, brain microglia and macrophages, activates $\alpha$-amino-3-hydroxy-5-methyl-4-isoxazolepropionic acid receptor (AMPA) receptors, increases calcium influx and exacerbates synaptic toxicity and neuronal loss (Steinman 2001). Oxidative injury, excessive mitochondrial dysfunction (Lassmann 2014) and age-dependent accumulation of iron within the CNS (Lassmann 2014) are also postulated to play a significant role in the progress of the disease as well.

Besides, reactivated memory B cells within the CNS can also lead components of the complement into damaging the myelin sheaths, as well as locally activating $\mathrm{T}$ cells; and vice versa (Reindl et al. 2010). Moreover, antibodies, either secreted by the B cells that migrated into the CNS or circulating in serum and then extravasated due to BBB disruption (Conlon et al. 1999; Palanichamy et al. 2014; Stern et al. 2014), contribute to the damaging processes. It has long been proven that the BBB disruption permits the penetration of antibodies targeting nonbrain antigens, in the entirety of the brain (Baloyannis and Gonatas 1979). These antibodies can trigger a crossresponse not only against a wide array of myelin components, but also against other CNS elements, for instance in the nodes of Ranvier of the axons (Levin et al. 2013) and glial cells (Fraussen et al. 2014).

Regarding the aforementioned memory B cells, once in the CNS, they can differentiate into CSF plasmablasts, the main antibody-secreting cells in the CSF. Additionally, expanded B lymphocyte and plasma cell clones can be found in the CSF of certain patients, sometimes as early as after the first MS attack (Haubold et al. 2004; Qin et al. 2003). The plasmablasts are responsible for the intrathecal production of immunoglobulins (Ig), a reliable biochemical marker of MS, known as oligoclonal bands (OCBs) (Cepok et al. 2005; von Büdingen et al. 2010). Interestingly, the levels of intrathecal IgG have been shown to correlate with the multitude, degree and size of gadolinium-enhanced lesions on brain magnetic resonance imaging (MRI) (Lucchinetti et al. 2000), parenchymal inflammation and disease severity (Cepok et al. 2005). Finally, the existence of activated complement proteins can be documented in the CSF of MS patients, alongside membrane-attack complexes, as the final point of a multidimensional pathway (Steinman 2001).

In a more clinical note, MS has four phenotypes: Relapsing Remitting (RR), Secondary Progressive (SP) - with relapses, Secondary Progressive (SP) - without relapses, and Primary Progressive (PP). The relapses of the first two types, with the concomitant axonal damage, seem to be dominated by generalized inflammation (Keegan and Noseworthy 2002), whereas the chronic progression toward primary forms has more obvious similarities with other neurodegenerative diseases (Compston and Coles 2002; Peterson and Fujinami 2007), where inflammation is more compartmentalized within the CNS, in ectopic lymphoid follicles particularly in the meninges (Grigoriadis et al. 2015; Serafini et al. 2004). Although this lymphoid tissue may be behind the appearance of the MS-typical subpial cortical demyelination (Magliozzi et al. 2007), deep gray matter "plaques" can already be seen in early disease stages and cannot be attributed to these inflammatory cells (Haider et al. 2014).

\section{MS as a potentially post-viral phenomenon}

\section{Evidence}

Existing data from observations and studies in a variety of fields, suggest that an environmental agent plays a significant role in the onset and pathogenesis of MS. Studies of monozygotic twins that developed MS, showed that both twins develop MS in only 30\% of the cases (Spielman and Nathanson 1982), while transcriptomic and epigenomic analyses of CD4+ lymphocytes from three MS-discordant twin sets reported no consistent differences that could explain the manifestation of the disease in only one of the twins (Baranzini et al. 2010). As such, childhood exposure in genetically predisposed individuals is supposed to be heavily involved in MS mechanisms, with viral infections being the most likely candidate (Johnson 1994; Kurtzke 1993; Marrodan et al. 2019).

One of the first and strong indications of this viral hypothesis were the "MS epidemics" in the Faroe Islands. MS was unknown to the native inhabitants of the islands before the year of 1943, i.e. three years after British troops had invaded and then resided in the islands (Kurtzke and Hyllested 1979). Since then, other "MS epidemics" and clusters have also been reported (Brown 2016) and related studies have considerably added to our epidemiological knowledge on the matter (Sospedra and Martin 2005). 
One such study involved descendants of immigrants from low MS-incidence countries to the United Kingdom, whose MS rates were comparable to the indigenous British population, and not to those of their countries of origin (Elian et al. 1990).

Indirect evidence that a virus may be associated with MS has come from experimentally caused viral infections in animals, and naturally occurring infections in humans. In these animal experiments, many viruses could induce demyelinating diseases in mammals (Johnson 1994; Soldan and Jacobson 2001; Wroblewska et al. 1979), and CoVs were a recurring protagonist in these studies, as mentioned above. Additionally, viral infections in humans can lead, under specific circumstances, to chronic neurologic sequalae and demyelination. One such example is progressive multifocal leukoencephalopathy (PML), a human demyelinating disease with a known viral cause; the John Cunningham papova virus (JCV). This virus selectively infects oligodendrocytes and creates foci of demyelination (Owens et al. 2011). Other paradigms are postinfectious encephalitis, subacute sclerosing panencephalitis (SSPE), caused by the measles virus (Garg et al. 2019), and HIV encephalitis and myelitis (Johnson 1994; Morgello 2018; Soldan and Jacobson 2001). Acute disseminated encephalomyelitis (ADEM) can also occur after viral infections, CoVs included (Yeh et al. 2004), and vaccinations, but at a lower rate than in a natural infection (Menge et al. 2005).

Moreover, several studies have correlated MS with specific viruses, such as Human Herpes Virus 6 (HHV-6), Epstein-Barr Virus (EBV), Varicella Zoster Virus (VZV), Cytomegalovirus (CMV), Human Endogenous Retrovirus (HERV), measles virus, influenza virus (Jaquiéry et al. 2010; Lossius et al. 2014; Mentis et al. 2017; Tselis 2011; Virtanen and Jacobson 2012) and CoVs as well, as we shall analyze in a section to come. IgG antibodies against several viruses have been identified in CSF samples of MS patients (Mentis et al. 2017) and viral particles after relapses of RRMS patients (Sotelo et al. 2008). Furthermore, the characteristic feature of elevated IgGs in the CSF of MS patients, the aforementioned OCBs (Kabat and Freedman 1950), points to a CNS disorder of infectious origin (Owens et al. 2011). In other chronic infections of the CNS, such as tuberculous or fungal meningitis, SSPE and neurosyphilis, the noted OCBs are mainly antibodies against the etiopathogenic agent (Porter et al. 1977; Vandvik et al. 1976; Vartdal et al. 1982). Although the antibodies in MS might indeed hold some immunopathologic value, this does not rule out the existence of cell-mediated immunopathology following a viral infection (Owens et al. 2011).
As can be deduced, there is evidence to suggest that viruses may be the triggering factor of immunopathogenic events driving the demyelination noted in MS (Baloyannis 2020; Murray et al. 1992a). Additionally, as several studies have showcased, MS patients have abnormal immune responses to viruses and infections in general, most commonly against upper respiratory tract infections, which can potentially lead to subsequent or coincident relapses (Edwards et al. 1998; Johnson 1994; Mailand and Frederiksen 2017; Marrodan et al. 2019; Sibley et al. 1985). As regards vaccinations, it seems that they are in general beneficial for MS patients, especially considering that they are frequently under immunosuppressive treatment (Garg et al. 2019; Mailand and Frederiksen 2017).

\section{Possible mechanisms}

In general, the nervous system damage that follows a viral attack may be the result of the immune system's activation rather than the direct effect of the pathogen (Klein et al. 2017). Here, we attempt to summarize the theories that have been formulated in this context, in order to try to explain the pathogenetic mechanisms that may trigger autoimmunity and lead to MS, after a viral infection. A combination of some of the below-mentioned mechanisms is most likely at play (Sospedra and Martin 2005).

- "Molecular mimicry" is defined as the activation of autoreactive cells against antigens of their own organism, due to similar sequences between foreign, in this case viral, and self-peptides (Fujinami and Oldstone 1985; Kohm et al. 2003). Several viruses, such as EBV, HHV-6, influenza and measles, possess genes that encode proteins with similar sequences with human myelin (Steinman 2001; Wucherpfennig et al. 1997). Autoantibodies and autoreactive $T$ cells that target myelin antigens, such as myelin basic protein (MBP), myelin proteolipid protein (PLP), myelin oligodendrocyte protein (MOG) and myelin associated glycoprotein (Tuohy et al. 1997), have also been found in MS patients (Garren et al. 1998; Wucherpfennig et al. 1997). MBP in particular, is the major EAE-inducing myelin antigen in the CNS (Fujinami and Oldstone 1985; Swanborg 1988). It has been further demonstrated that a naturally occurring infection with a virus that expressed an epitope similar to human myelin, can cause an immune-mediated demyelinating disease in mice, via molecular mimicry (Olson et al. 2001). Finally, a study in pre- and post-vaccinated individuals has reported antigenic mimicry and 
immunological cross-reactivity involving Hepatitis B surface antigen and myelin antigens following vaccination, though none of the healthy individuals who were vaccinated for hepatitis B virus developed MS (Bogdanos et al. 2005).

- "Epitope spreading" is the activated immune response against other antigenic epitopes, besides the primary one. Intramolecular spreading refers to epitopes on the same molecule, whereas intermolecular spreading refers to epitopes on different molecules. This can also occur upon CNS damage, which provides plenty new self-antigens, after a persistent virus infection (Grigoriadis and Hadjigeorgiou 2006; Tuohy et al. 1997). On the basis of that mechanism, PLP was experimentally shown to stimulate lymphocytes from mice, chronically infected with Theiler's murine encephalomyelitis virus (TMEV), leading them to provoke myelin sheath destruction in organotypic cultures (Dal Canto et al. 2000).

- "Bystander activation" is the concomitant activation of autoreactive cells due to the surrounding nonspecific inflammatory environment, following a viral infection (Fujinami et al. 2006).

- "Superantigens" are antigens that possess the ability to activate $\mathrm{T}$ cells specific for other self-antigens and have also been shown to reactivate EAE processes (Marrodan et al. 2019; Schiffenbauer et al. 1993).

- “Cryptic antigens" may be exposed and activated during a supervened infection and induce another wave of immune response, which can consequently attack the CNS and trigger autoimmune responses (Marrodan et al. 2019; Sfriso et al. 2010).

Finally, Lucchinetti et al. in 2000, described four fundamental patterns of demyelination in MS lesions, differentiated by the topography of myelin loss, the extension of the demyelination plaques, the oligodendrocyte depletion and the complement involvement. Two of them resemble T-cell mediated processes, but two of them present features of primary oligodendrocyte dystrophy, something that hints toward processes induced by viruses or toxins (Lucchinetti et al. 2000).

\section{Presence of coronaviruses in MS}

\section{Brain tissue}

As already mentioned, CoVs were found in the CNS of MS patients from the first years of their appearance in humans, and for this reason suspicion regarding their causal relationship with MS was raised. Moreover, it has been demonstrated that the initial $\mathrm{CoV}$ infections and the subsequently built immunity, typically occur in late childhood, when the establishment of environmental exposure to the various possible MS risk factors is thought to take place (Fleming et al. 1988). CoVs have been since detected in various other neurological diseases, including Alzheimer's disease, Parkinson's disease (Hovanec and Flanagan 1983) and ADEM (Yeh et al. 2004), but most commonly in tissues from MS patients (Arbour et al. 2000; Murray et al. 1992a, 1992b). HCoV-229E and HCoV-OC43 were more frequently encountered (Hovanec and Flanagan 1983), and in a significantly higher rate than in control individuals (Arbour et al. 2000).

More specifically, earlier studies have found CoV elements, such as specific antigens and RNA, in MS brain specimens (Murray et al. 1992a; Murray et al. 1993; Stewart et al. 1992) through several detection methods (Burks et al. 1980; Murray et al. 1992a; Stewart et al. 1992), and more importantly, in plaques with ongoing demyelination (Murray et al. 1992a).

\section{Cerebrospinal fluid}

An early study on CSF samples from MS patients reported that $\mathrm{CoV}$ antibodies were found in more patients and in higher levels than in controls, while intrathecal antibody synthesis against $\mathrm{HCoV}-\mathrm{OC} 43$ and $\mathrm{HCoV}-229 \mathrm{E}$ viruses was only documented in samples of MS patients, and not at all in the control group (Salmi et al. 1982). However, another study found an increase in positive CSF responses against $\mathrm{HCoV}$-OC43 in MS patients, but this could not reach the significance threshold (Fleming et al. 1988). In addition, CoV-RNAs have been extracted from CSF samples of MS patients, but also from patients with other neurological disorders, such as Parkinson's disease, dementia, and polyneuropathy (Cristallo et al. 1997), so this reduced the specificity of this findings, albeit tying CoVs to neurological disorders.

\section{Serum antibodies}

A line of studies has delved into the comparison of serum antibodies against CoVs titers between MS patients and healthy individuals. Some reported that although most of the population carries antibodies against CoVs, MS patients had slightly more elevated titers (Burks et al. 1980). This was not reciprocated in other studies, where the noted differences could not reach statistical significance, though this could have been the result of methodological 
discrepancies (Hovanec and Flanagan 1983; Madden et al. 1981; Salmi et al. 1982). In any case, these studies do not present evidence strong enough that CoVs are or are not causally associated with MS (Fleming et al. 1982). Indeed, $\mathrm{CoVs}$ are ubiquitous in nature and their infections, asymptomatic or not, are very common, so investigating a possible association with neurological diseases cannot be accurately done on serological grounds only. This is not only encountered with CoVs; JCV is usually present in the general population but can only lead to PML under specific circumstances. And finally, serum findings do not reflect the immunological processes taking place within the CNS, since several studies have also shown that serum antiviral antibody levels do not correlate with the degree of viral activity and disease severity in the CNS (Fleming et al. 1982; Stohlman and Weiner 1981).

\section{Leukocytes}

An interesting study by Talbot et al. in 1996, isolated T cells from 16 MS patients and 14 healthy controls and showed that the cells stemming from the patients exhibited crossreactivity between the MBP protein and HCoV-229E antigens at a much higher rate than healthy donor cells (Talbot et al. 1996). These findings support the notion that molecular mimicry may indeed be a possible immunopathological mechanism in MS.

\section{CoV-induced demyelinating disease: an MS-mimic in animal models}

\section{Common elements with MS}

Many experimental studies in animal models, mainly from the last half of the 20th century, proved that CoVs can induce demyelination in the CNS of infected animals (Bailey et al. 1949; Herndon et al. 1975; Lane and Hosking 2010; Lavi et al. 1984; Nagashima et al. 1978; Pappenheimer 1958), primates included (Cabirac et al. 1993). This CoV-induced Demyelinating Disease (CIDD) shares several features with MS (Lavi et al. 1999), including genetic susceptibility (Knobler et al. 1984; Owens et al. 2011; Stohlman and Frelinger 1978), multiple and recurrent demyelinating lesions affecting only the CNS (Nagashima et al. 1978), chronic demyelination (Fleming et al. 1988; Herndon et al. 1975) with a relapsing and remitting character (Wege et al. 1983), several histopathological features (Cheever and
Daniels 1949; Lampert et al. 1973), such as extra- and intracellular vacuolation and neuronal loss (Lavi et al. 1984), and immunologic abnormalities, including intrathecal antibody synthesis and oligoclonal CSF antibody (Dörries et al. 1986; Fleming et al. 1983). As previously mentioned, MHV is the main strand that has been used in the animal projects that explored CIDD, and more specifically its neurotropic strain, JHM, but similar studies have been conducted with other CoVs as well (Brison et al. 2011; Fleming et al. 1988). MHV is also genetically related to HCoV-OC43 (Bergmann et al. 2006; Jacomy and Talbot 2003), so it is reasonable to assume that many similarities amongst the two exist.

\section{Course and pathophysiology of CoV-induced demyelinating disease}

The course of CIDD is in many cases biphasic (Lavi et al. 1984). First, it develops as an acute demyelinating encephalomyelitis (Dandekar et al. 2003) or mild encephalitis/meningoencephalitis (Lavi et al. 1984), and then a late onset symptomatic demyelinating disease (Lau et al. 2004), or otherwise a chronic demyelinating disease, is developed (Gonzales et al. 2004; Lavi et al. 1984), which is similar to MS. This MS-like demyelinating procedure has also been used as a model for MS in experimental studies (Houtman and Fleming 1996). As mentioned above, already since 1947, scientists have noticed brain and spinal cord lesions in of pure inflammation, combined with diffuse demyelination of CNS nerve tracts, in the acute phase of CIDD (Cheever and Daniels 1949). Viral replication was abundant in white and gray matter alike (Jordan et al. 1989), though viral antigens were most frequently encountered in white matter cells (Nagashima et al. 1978), leading directly to demyelination via infection of glial cells (Jordan et al. 1989; Lavi et al. 1984; Weiner 1973). Additional findings are those of inflammatory cells, oligodendrocyte depletion and a considerable reduction in myelin gene transcription products (Jordan et al. 1989). A few weeks after infection, no viral transcripts are usually found, while the myelin genes become steadily more transcribed and the remyelination commences (Jordan et al. 1989). This first type of demyelination was considered to stem from the direct destruction of oligodendrocytes from the virus itself (Cheever and Daniels 1949; Lampert et al. 1973). Interestingly, in a CIDD study, antibodies were detected in the lesions on the 6th post infection day, although CoVs could be detected in the CNS only after the 12th (Mendelman et al. 1983), which advocates for demyelination as a consequence of an immunological response. 
In the second phase of the disease, animals have been shown to develop neurological signs from the 6th (Nagashima et al. 1978) until the 16th month after the infection (Herndon et al. 1975). The morphological examination revealed patterns of RRMS, i.e. chronic demyelination (Herndon et al. 1975), remyelination and new active demyelinating lesions (Nagashima et al. 1978). In asymptomatic mice, JHM virus-like particles that resembled the JHM virus were detected in cells in closeness, proximity to demyelinating regions (Herndon et al. 1975). In CIDD, the presence of virions in oligodendrocytes has not been proven. This opposes the case of acute CoV-induced demyelination, where the direct infection of oligodendrocytes is a typical feature (Lampert et al. 1973). In this late demyelination, the delayed nature of lesions suggests an immunopathologic process (Lampert et al. 1973), while the subacute or chronic demyelinating state is characterized by an abundance of plasma cells and mononuclear cells, which create the so-called perivascular cuffings (Nagashima et al. 1978).

This late onset demyelinating encephalomyelitis indicates that $\mathrm{CoV}$, upon infiltrating the CNS, has the capability of triggering autoimmune responses, probably via T-cell mediated immune reactions against antigens (Kyuwa et al. 1991; Murray et al. 1993; Stohlman and Weiner 1981; Watanabe et al. 1983), promoting demyelination (Owens et al. 2011; Wu et al. 2000). An early study had shown that MBP could restimulate lymphocytes from diseased rats and when these cells were reinstituted to tissues, the transfer led to the creation of lesions similar to those of EAE (Watanabe et al. 1983). This cross-reaction of autoreactive lymphocytes with both CoV antigens and human myelin, underlines the molecular mimicry as an important mechanism via which $\mathrm{CoV}$ can possibly induce autoimmune CNS diseases (Desforges et al. 2020). In addition, bystander CD8+ T-cell-mediated demyelination has also been reported, in which IFN-y activates macrophages/microglia (Dandekar et al. 2004; Haring et al. 2002). Moreover, the CoV infection of pericytes, macrophages, microglia and astrocytes, and the persistence of the viral infection are also important factors and can lead to a pro-inflammatory state, which could in turn favor autoimmunity (Li et al. 2004).

In view of all these, we now know that CoVs can damage the CNS not only via a direct damage of CNS cells (virus-induced neuropathology), but also via misdirected host immune responses (virus-induced neuroimmunopathology), which can trigger autoimmunity in genetically predisposed individuals (Desforges et al. 2014), since it has been shown that multiple strains of CoVs have produced immunemediated demyelination (Owens et al. 2011).

\section{Covid-19, autoimmunity and demyelination}

In the light of the current Covid-19 pandemia, there is a lot of discussion and research about the relationship between SARS-CoV-2 and autoimmune diseases. The SARS-CoV-2 infection actually shares similarities with autoimmune diseases in terms of clinical manifestations, immune reactions and pathogenetic mechanisms (Liu et al. 2021). Some cases of diagnosed autoimmune diseases have been also reported after SARS-CoV-2 infection (Ehrenfeld et al. 2020; Galeotti and Bayry 2020), such as systemic lupus erythematosus (SLE) (Liu et al. 2021), immune thrombocytopenic purpura (ITP) (Zulfiqar et al. 2020), pediatric inflammatory multisystemic syndrome (PIMS), which includes Kawasaki-like disease in children (Galeotti and Bayry 2020; Gkoutzourelas et al. 2020), and as regards the PNS, Miller-Fisher (Gutiérrez-Ortiz et al. 2020) and Guillain-Barré syndrome (GBS) (Alberti et al. 2020; Coen et al. 2020; Juliao Caamaño and Alonso Beato 2020; Ottaviani et al. 2020; Toscano et al. 2020). Immunologic reactions after a SARS-CoV-2 infection can also affect the CNS and may even cause inflammatory injury and edema (Wu et al. 2020; Ye et al. 2020), or encephalitis/meningoencephalitis (Bernard-Valnet et al. 2020; Moriguchi et al. 2020; Ye et al. 2020) and vascular manifestations (Ehrenfeld et al. 2020; Oxley et al. 2020), associated in a few occasions with antiphospholipid antibodies (Ehrenfeld et al. 2020; Zhang et al. 2020). Autoimmune disorders of the nervous system have been described following infections by previous HCoV infections as well (Tsai et al. 2005; Kim et al. 2017).

More importantly, cases of Acute Disseminated Encephalomyelitis (ADEM) have also been reported upon SARS-CoV-2 infection (Novi et al. 2020; Parsons et al. 2020; Paterson et al. 2020; Reichard et al. 2020; Zhang et al. 2021) and with previously known CoV infections (Arabi et al. 2015; Yeh et al. 2004). Demyelination during or after covid-19 infection has been observed in CNS, in intracranial and spinal regions (Canavero et al. 2021; Ismail and Salama 2022; Terruzzi et al. 2021; Zanin et al. 2020; Zoghi et al. 2020), and SARS-CoV-2-associated myelitis with type 4 or type 2 OCBs has been described as well (Espíndola et al. 2020; Karsidag et al. 2021). Some interesting cases that have been so far described and are worth mentioned, are an acute tumefactive demyelination in CNS (Agarwal et al. 2020), an acute haemorrhagic leukoencephalitis (Weston Hurst syndrome, AHLE), a fulminant variant of ADEM, with macroscopic hemorrhage and a concentric demyelination pattern (Karapanayiotides et al. 2020), an isolated symmetrical internal capsule demyelination (Khandelwal et al. 2021), and a multifocal demyelinating neuropathy that 
included peripheral nerves and the optic nerve as well (Elavarasi et al. 2021). Karsidag et al. described two patients with post-covid demyelination in CNS, with two episodes each of them, MRI findings with distribution in time and space, and high IgG index (one of them with OCBs type 2) supporting a diagnosis of MS according to McDonald criteria (Karsidag et al. 2021). However, the appearance of these plaques was atypical for MS, and Karsidag et al. concluded that Covid-19 infection may result in demyelination also through small-vessel vasculitis that can affect myelin sheaths (Karsidag et al. 2021). According to the above findings, it seems that SARS-CoV-2, like other members of its family, can cause demyelination in CNS of humans.

Additionally, OCBs were detected in the CSF of some patients with other neurological symptoms, implying the implication of immune-mediated processes in neurological manifestations of SARS-CoV-2 (Espíndola et al. 2020). In general, antigen-specific autoantibodies, the hallmarks of autoimmune diseases, have been detected in Covid-19 patients as well (Liu et al. 2021). Such circulating autoantibodies have been found in some Covid-19 patients with known various autoimmune diseases (Halpert and Shoenfeld 2020) and researchers support that SARS-CoV-2 proteins can induce the production of newly-formed IgG autoantibodies in a significant number of hospitalized Covid-19 patients (Chang et al. 2021). The frequent detection of autoantibodies targeting the CNS, in many cases in the absence of SARS-CoV-2 in the CSF of Covid-19 patients (Neumann et al. 2020), may suggest a causal relationship between autoimmune procedures and the neurological manifestations of SARS-CoV-2, which may be mediated by cellular or humoral autoimmunity, similar to other viral diseases (Franke et al. 2021). Similarly, patients treated in intensive care units could present neurological symptoms without detection of SARS-CoV-2 in their CSF (Franke et al. 2021). Postmortem examinations in brains from Covid-19 patients revealed that the presence of the virus in the CNS did not necessarily denote encephalitis (Serrano et al. 2021) and was not associated with the severity of the CNS damage, thus challenging the theory of it being directly induced by the virus (Matschke et al. 2020).

\section{Covid-19 and MS}

As can be so far understood, SARS-CoV-2 is in the capacity of inducing autoimmune reactions and causing demyelination in humans, raising the question of whether it may be associated with MS as well. To our knowledge, one case of a patient with mild respiratory symptoms and an incomplete cervical spinal cord syndrome, has been reported as a clinically isolated syndrome (CIS) (Domingues et al. 2020). Another patient was actually found to fulfill the diagnostic criteria for MS, though it was assumed that the pathogenic processes had begun before the SARS-CoV-2 infection and were reactivated by the virus (Palao et al. 2020). The patients of Karsidag et al. that we have described above, could also fulfill the McDonald criteria for MS (Karsidag et al. 2021). Concerning already-diagnosed MS patients, relapses during an otherwise asymptomatic SARS-CoV-2 infection have been reported (Florea et al. 2021). However, general susceptibility toward SARS-CoV-2 and severity of disease seem to be principally dictated by the same factors as in non-MS patients (Zabalza et al. 2021); in a postmortem case study, direct evidence for neuronal or glial cell infection was found neither in healthy nor in demyelinated areas, despite the evidence for residual BBB leakage in the examined SARS-CoV-2 infected MS patient (Fuchs et al. 2021).

The most plausible mechanisms behind SARS-CoV-2 associating with MS are molecular mimicry between autoantigens and viral antigens (Figure 4), and a delayed activation of autoimmunity post infection (Franke et al. 2021). In SARS-CoV-2 patients with neurological symptoms, anti-neuronal and anti-glial autoantibodies in CSF were more frequently encountered than in patients without such manifestations (Franke et al. 2021). Anti-neuronal autoantibodies have also been found in serum of SARS-CoV-2 patients and the targeted antigens were intracellular and neuronal surface proteins, vessel endothelium and astrocytic proteins (Franke et al. 2021), structures that are crucial in the development of MS. Another study found that the SARS-CoV-2 Spike (S) protein antibodies can strongly cross-react with MBP, among other tissue proteins (Vojdani and Kharrazian 2020). This proof of specific virus-combating antibodies cross-reacting with CNS structures implicates specific autoimmunity in tying MS and the Covid-19 pandemia.

Previous studies with other HCoVs have shown that autoreactive $\mathrm{T}$ cells can lead to T-cell-associated myelin destruction in MS patients, as the cells can target myelin proteins, namely MBP and PLP (Boucher et al. 2007; Talbot et al. 1996). More specifically, one study had reported that almost one in three of the peripheral T-cell lines isolated from 10 out of 16 MS patients reacted against both $\mathrm{HCoV}$ and myelin proteins, in contrast to only two out of 14 isolated from control individuals (Talbot et al. 1996). As such, SARS-CoV-2 antibodies may also cross-react with myelin and lead to demyelination.

Moving on, in the pathogenesis of these autoimmune diseases, cytokines, fever and hyperferritinhemia (Halpert 


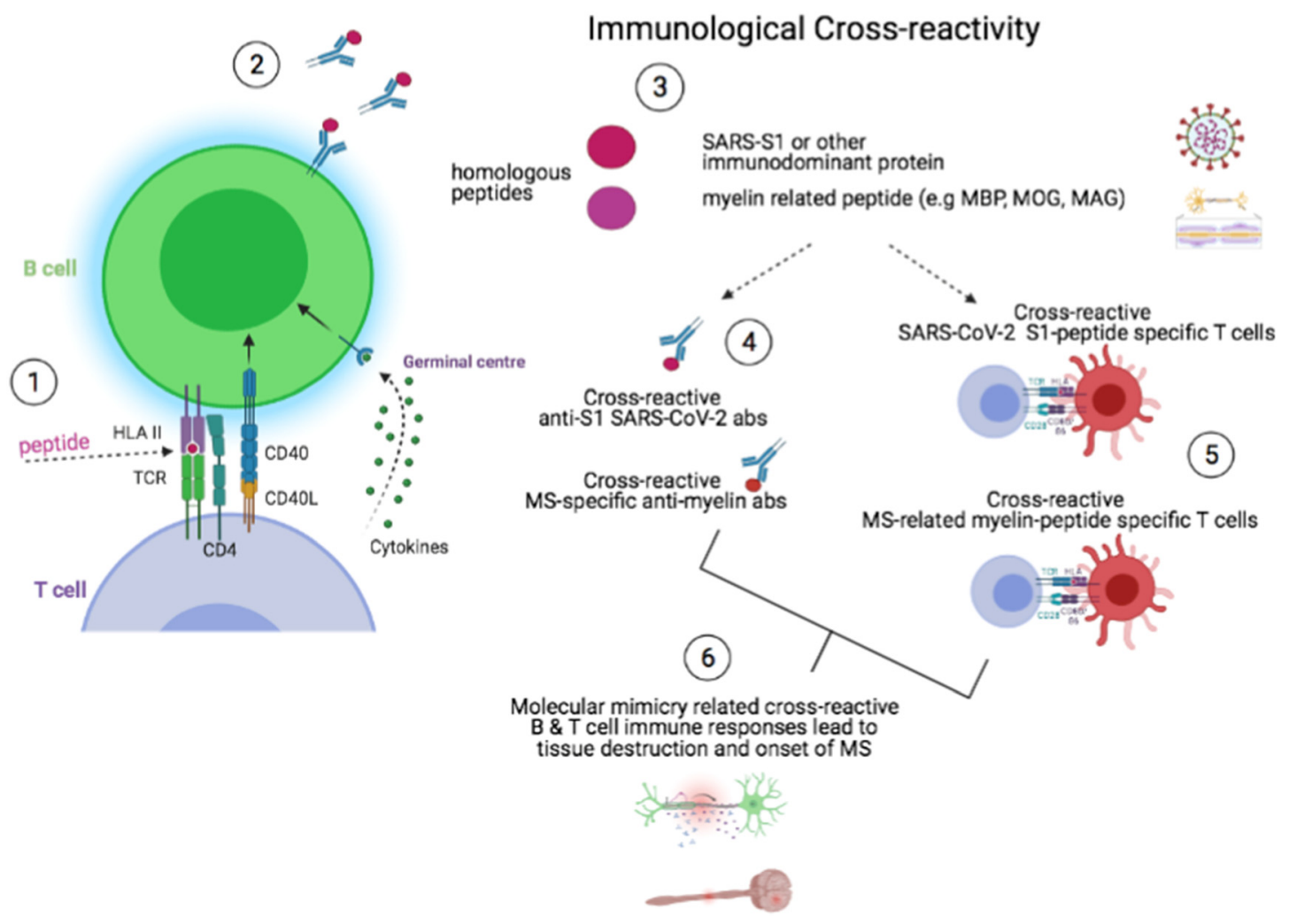

Figure 4: A hypothesis of immunological cross-reactivity implicating homologous SARS-CoV-2 and MS-specific autoantigens leading to disease onset.

(A) An adaptive immune response initiated upon exposure to SARS-CoV-2 infection induces B-and T-cell responses against specific viral immunodominant epitopes. (B) The immune response activates peptide-specific T-cells and SARS-CoV-2 specific antibodies (such as those against the spike protein S1 of the virus). (C) If the immunodominant epitopes of the virus share antigenic mimicry with MS, cross-reactive antibodies are induced against myelin or other related autoantigen epitopes (D), as well as antigen-specific T-cell responses crossrecognizing the homologous epitopes (E). Thus, molecular mimicry and immunological cross-reactive adaptive immune responses may account for cell/tissue destruction and initiation of full-blown disease (F). The Figure was prepared using the BioRender platform (under license to DPB).

and Shoenfeld 2020) are thought to play a significant role (Low et al. 2020), while indirect effects caused by systemic reactions to critical illness may further lead to neurological manifestations (Serrano et al. 2021). It was reported that early anti-inflammatory intervention in patients with severe SARS-CoV-2 pneumonia with a systemic inflammatory response syndrome (SIRS) could protect against immune-mediated damage and nervous system damage (Fu et al. 2020; Mehta et al. 2020). This inflammation and the deregulation of immune responses after a SARS-CoV-2 infection might assist other environmental factors in triggering autoimmune disorders in susceptible individuals (Galeotti and Bayry 2020).

As already mentioned, CoVs can infect leukocytes, such as monocytes/macrophages (Collins 2002; Desforges et al. 2007; Gu et al. 2005), and dendritic cells, expressing the human aminopeptidase N (Mesel-Lemoine et al. 2012; Wentworth et al. 2005), and can thus migrate into other tissues, the CNS being included (Lima et al. 2020). In this process, the viral S glycoprotein constitutes an important player in neurodegeneration and neurovirulence (Brison et al. 2011; Jacomy et al. 2010), and in the ability of CoVs to persistently infect host cells (Arbour et al. 2000; Desforges et al. 2007). In this way, they can "modulate" the immune system and establish a persistent presence in a human leukocyte (Desforges et al. 2007; Lima et al. 2020). Immune and neural cells can thus become reservoirs of latent $\mathrm{CoV}$, possibly paving the way to neurodegenerative processes, that develop after the acute phase (Desforges et al. 2020) and to manifestations such as encephalomyelitis and MS (Lau et al. 2004; Talbot and Falsey 2010; Yeh et al. 2004; Zlateva and Van Ranst 2004). It is well known that chronic inflammation in the body can potentially induce autoimmune diseases (Vojdani and Kharrazian 2020). The constant presence of CoVs in the CNS, combined with the simultaneous inflammation may be responsible for the 
development and/or the exacerbation of chronic neurological disorders (Arbour et al. 2000; Cristallo et al. 1997; Stewart et al. 1992). Regarding SARS-CoV-2 in particular, the immune-mediated demyelination is thought to stem from the virus' presence in oligodendrocytes (DosSantos et al. 2020). Moreover, Angiotensin-converting enzyme 2 (ACE2) receptor, a known SARS-CoV-2 receptor, is expressed in brain cells and in oligodendrocyte progenitor cells too. Consequently, SARS-CoV-2 can hinder oligodendrocyte differentiation and myelin repair, aggravating chronic and progressive demyelinating conditions (Chen et al. 2020; Meshkat et al. 2020)

Last but not least, the results of a recent study suggested that SARS-CoV-2 can alter human proteins, which can in turn be falsely recognized from the immune system as foreign and induce an autoimmune attack (Wang et al. 2021). In particular, 150 altered proteins have been found, which bear ties with the nervous system, including axon and myelin sheath proteins. Their existence supports the hypothesis that SARS-CoV-2 can indeed spur autoimmunity in the CNS (Wang et al. 2021).

Coming back to the original question of whether this pandemia viral disease might raise the numbers of MS patients in the years to come, the current prevalence of the disease in countries heavily afflicted by the pandemia need to be studied. Regarding the United States (US), a cumulative approach based on health claims data, published in 2019, calculated the 2010 US prevalence at 309.2 per 100,000, and estimated the 2017 prevalence between 337.9 and 362.6 per 100,000 (Wallin et al. 2019). Based on previous records, the prevalence of MS is on the rise due to various preexisting factors, but whether the pandemia would give a further boost to it or not, remains to be established within the next five to 10 years, if it surpasses this prediction. Regarding a country quite different from US, the MS prevalence in Brazil seems to heavily vary from region to region, and to be much lower than in the US; a 2015 systematic review placed its prevalence from 1.36 to 27.2 per 100,000 (da Gama Pereira et al. 2015). This is not a surprise since MS prevalence has been shown to increase as geographic latitude increases (Wood 2017). However, Brazil has had one of the fastest SARS-CoV-2 spreads (Lobo et al. 2020) and death counts worldwide (Melo et al. 2020), while vaccination efforts have delayed considerably, in comparison to other countries. As such, with this viral burden, it shall be particularly interesting to monitor MS prevalence and incidence rates in Brazil in the years to come, since with this low number of MS patients, an increasing trend, possibly due to the pandemia, would be easier to be evaluated.

\section{Conclusions}

The occurrence of the Covid-19 pandemia, the impact that CoVs and SARS-CoV-2 seem to have on the activation of autoimmunity, and the ability of CoVs to lead to demyelination in the CNS, have brought the viral hypothesis of MS to the consideration again. Data from experimental studies with $\mathrm{CoV}$ infections that can induce an MS-like demyelinating disease, epidemiological data and findings from MS patients, the known extent of MS pathophysiology that supports the existence of an environmental factor that could trigger autoimmune and pathological reactions in genetically predisposed individuals, are all adding to new data from the current pandemia and have given hypostasis to the viral theory and especially regarding CoVs. According to the recent findings, SARS-CoV-2 could indeed trigger demyelination and autoimmune reactions, and it would be possible that the rate of autoimmune diseases, and MS as well, may raise in the coming years. If this is true, younger ages are in greater risk of autoimmune diseases and MS, so these populations should be more closely monitored. More research needs to be conducted in order to try to answer these emerging questions, and to propose health and vaccination policies that will look to the future and attempt to prevent, in any possible way, an increase in the prevalence of MS. It is yet to be seen, whether the frequency of MS is going to rise in the post-Covid-19 pandemia era.

Author contributions: All the authors have accepted responsibility for the entire content of this submitted manuscript and approved submission.

Research funding: None declared.

Conflict of interest statement: The authors declare no conflicts of interest regarding this article.

\section{References}

Agarwal, A., Pinho, M., Raj, K., Yu, F.F., Bathla, G., Achilleos, M., Thomas, O.N., Still, M., and Maldjian, J. (2020). Neurological emergencies associated with COVID-19: stroke and beyond. Emerg. Radiol. 27: 747-754.

Alberti, P., Beretta, S., Piatti, M., Karantzoulis, A., Piatti, M.L., Santoro, P., Viganò, M., Giovannelli, G., Pirro, F., Montisano, D.A., et al. (2020). Guillain-Barré syndrome related to COVID-19 infection. Neurol Neuroimmunol Neuroinflamm 7: 4.

Arabi, Y.M., Harthi, A., Hussein, J., Bouchama, A., Johani, S., Hajeer, A.H., Saeed, B.T., Wahbi, A., Saedy, A., AlDabbagh, T., et al. (2015). Severe neurologic syndrome associated with Middle East respiratory syndrome corona virus (MERS-CoV). Infection 43: 495-501. 
Arbour, N., Day, R., Newcombe, J., and Talbot, P.J. (2000). Neuroinvasion by human respiratory coronaviruses. J. Virol. 74: 8913-8921.

Bailey, O.T., Pappenheimer, A.M., Cheever, F.S., and Daniels, J.B. (1949). A murine virus (JHM) causing disseminated encephalomyelitis with extensive destruction of myelin: II. Pathology. J. Exp. Med. 90: 195-212.

Baloyannis, S.J. (2020). In: Baloyannis, S.J. (Ed.). Introductory chapter: multiple sclerosis. Multiple sclerosis. London, United Kingdom: IntechOpen, pp. 3-11.

Baloyannis, S.J. and Gonatas, N.K. (1979). Distribution of anti-HRP antibodies in the central nervous system of immunized rats after disruption of the blood brain barrier. J. Neuropathol. Exp. Neurol. 38: $519-531$.

Baranzini, S.E., Mudge, J., van Velkinburgh, J.C., Khankhanian, P., Khrebtukova, I., Miller, N.A., Zhang, L., Farmer, A.D., Bell, C.J., Kim, R.W., et al. (2010). Genome, epigenome and RNA sequences of monozygotic twins discordant for multiple sclerosis. Nature 464: 1351-1356.

Bergmann, C.C., Lane, T.E., and Stohlman, S.A. (2006). Coronavirus infection of the central nervous system: host-virus stand-off. Nat. Rev. Microbiol. 4: 121-132.

Bernard-Valnet, R., Pizzarotti, B., Anichini, A., Demars, Y., Russo, E., Schmidhauser, M., Cerutti-Sola, J., Rossetti, A.O., and Du Pasquier, R. (2020). Two patients with acute meningoencephalitis concomitant with SARS-CoV-2 infection. Eur. J. Neurol. 27: e43-e44.

Bogdanos, D.P., Smith, H., Ma, Y., Baum, H., Mieli-Vergani, G., and Vergani, D. (2005). A study of molecular mimicry and immunological cross-reactivity between hepatitis B surface antigen and myelin mimics. Clin. Dev. Immunol. 12: 217-224.

Boucher, A., Denis, F., Duquette, P., and Talbot, P.J. (2001). Generation from multiple sclerosis patients of long-term T-cell clones that are activated by both human coronavirus and myelin antigens. Adv. Exp. Med. Biol. 494: 355-362.

Boucher, A., Desforges, M., Duquette, P., and Talbot, P.J. (2007). Longterm human coronavirus-myelin cross-reactive T-cell clones derived from multiple sclerosis patients. Clin. Immunol. 123: 258-267.

Brison, E., Jacomy, H., Desforges, M., and Talbot, P.J. (2011). Glutamate excitotoxicity is involved in the induction of paralysis in mice after infection by a human coronavirus with a single point mutation in its spike protein. J. Virol. 85: 12464-12473.

Brown, C. (2016). Aetiology: neighbourhood watch. Nature 540: S4-S6.

Burks, J.S., DeVald, B.L., Jankovsky, L.D., and Gerdes, J.C. (1980). Two coronaviruses isolated from central nervous system tissue of two multiple sclerosis patients. Science 209: 933-934.

Cabirac, G.F., Soike, K.F., Butunoi, C., Hoel, K., Johnson, S., Cai, G.Y., and Murray, R.S. (1993). Coronavirus JHM OMP1 pathogenesis in owl monkey CNS and coronavirus infection of owl monkey CNS via peripheral routes. Adv. Exp. Med. Biol. 342: 347-352.

Canavero, I., Ravaglia, S., Valentino, F., and Micieli, G. (2021). Guillain Barrè syndrome and myelitis associated with SARS-CoV-2 infection. Neurosci. Lett. 759: 136040.

Cepok, S., Rosche, B., Grummel, V., Vogel, F., Zhou, D., Sayn, J., Sommer, N., Hartung, H.-P., and Hemmer, B. (2005). Short-lived plasma blasts are the main $B$ cell effector subset during the course of multiple sclerosis. Brain 128: 1667-1676.

Chang, S.E., Feng, A., Meng, W., Apostolidis, S.A., Mack, E., Artandi, M., Barman, L., Bennett, K., Chakraborty, S., Chang, I., et al.
(2021). New-onset IgG autoantibodies in hospitalized patients with COVID-19. Nat. Commun. 12: 5417.

Cheever, F.S., Daniels, J.B. (1949). A murine virus (JHM) causing disseminated encephalomyelitis with extensive destruction of myelin. J. Exp. Med. 90: 181-210.

Chen, R., Wang, K., Yu, J., Howard, D., French, L., Chen, Z., Wen, C., and $\mathrm{Xu}, \mathrm{Z}$. (2020). The spatial and cell-type distribution of SARS-CoV2 receptor ACE2 in the human and mouse brains. Front. Neurol. 11: 573095.

Coen, M., Jeanson, G., Culebras Almeida, L.A., Hübers, A., Stierlin, F., Najjar, I., Ongaro, M., Moulin, K., Makrygianni, M., Leemann, B., et al. (2020). Guillain-Barré syndrome as a complication of SARS-CoV-2 infection. Brain Behav. Immun. 87: 111-112.

Collins, A.R. (2002). In vitro detection of apoptosis in monocytes/ macrophages infected with human coronavirus. Clin. Diagn. Lab. Immunol. 9: 1392-1395.

Compston, A. and Coles, A. (2002). Multiple sclerosis. Lancet 359: 1221-1231.

Compston, A. and Coles, A. (2008). Multiple sclerosis. Lancet 372: 1502-1517.

Conlon, P., Oksenberg, J.R., Zhang, J., and Steinman, L. (1999). The immunobiology of multiple sclerosis: an autoimmune disease of the central nervous system. Neurobiol. Dis. 6: 149-166.

Corman, V.M., Muth, D., Niemeyer, D., and Drosten, C. (2018). Hosts and sources of endemic human coronaviruses. Adv. Virus Res. 100: 163-188.

Cristallo, A., Gambaro, F., Biamonti, G., Ferrante, P., Battaglia, M., and Cereda, P.M. (1997). Human coronavirus polyadenylated RNA sequences in cerebrospinal fluid from multiple sclerosis patients. New Microbiol. 20: 105-114.

da Gama Pereira, A.B., Sampaio Lacativa, M.C., da Costa Pereira, F.F., and Papais Alvarenga, R.M. (2015). Prevalence of multiple sclerosis in Brazil: a systematic review. Mult Scler Relat Disord 4: 572-579.

Dal Canto, M.C., Calenoff, M.A., Miller, S.D., and Vanderlugt, C.L. (2000). Lymphocytes from mice chronically infected with Theiler's murine encephalomyelitis virus produce demyelination of organotypic cultures after stimulation with the major encephalitogenic epitope of myelin proteolipid protein. Epitope spreading in TMEV infection has functional activity. J. Neuroimmunol. 104: 79-84.

Dandekar, A.A., Anghelina, D., and Perlman, S. (2004). Bystander CD8 T-cell-mediated demyelination is interferon-gamma-dependent in a coronavirus model of multiple sclerosis. Am. J. Pathol. 164: 363-369.

Dandekar, A.A., Jacobsen, G., Waldschmidt, T.J., and Perlman, S. (2003). Antibody-mediated protection against cytotoxic T-cell escape in coronavirus-induced demyelination. J. Virol. 77: 11867-11874.

Dardiotis, E., Panayiotou, E., Provatas, A., Christodoulou, K., Hadjisavvas, A., Antoniades, A., Lourbopoulos, A., Pantzaris, M., Grigoriadis, N., Hadjigeorgiou, G.M., et al. (2017). Gene variants of adhesion molecules act as modifiers of disease severity in MS. Neurol. Neuroimmunol. Neuroinflamm 4: e350.

Dardiotis, E., Panayiotou, E., Siokas, V., Aloizou, A.M., Christodoulou, K., Hadjisavvas, A., Pantzaris, M., Grigoriadis, N., Hadjigeorgiou, G.M., and Kyriakides, T. (2019a). Gene variants of adhesion molecules predispose to MS: a case-control study. Neurol Genet 5: e304.

Dardiotis, E., Tsouris, Z., Aslanidou, P., Aloizou, A.M., Sokratous, M., Provatas, A., Siokas, V., Deretzi, G., and Hadjigeorgiou, G.M. 
(2019b). Body mass index in patients with Multiple Sclerosis: a meta-analysis. Neurol. Res. 41: 836-846.

Desforges, M., Le Coupanec, A., Dubeau, P., Bourgouin, A., Lajoie, L., Dubé, M., and Talbot, P.J. (2020). Human coronaviruses and other respiratory viruses: underestimated opportunistic pathogens of the central nervous system? Viruses 12: 14.

Desforges, M., Le Coupanec, A., Stodola, J.K., Meessen-Pinard, M., and Talbot, P.J. (2014). Human coronaviruses: viral and cellular factors involved in neuroinvasiveness and neuropathogenesis. Virus Res. 194: 145-158.

Desforges, M., Miletti, T.C., Gagnon, M., and Talbot, P.J. (2007). Activation of human monocytes after infection by human coronavirus 229E. Virus Res. 130: 228-240.

Domingues, R.B., Mendes-Correa, M.C., de Moura Leite, F.B.V., Sabino, E.C., Salarini, D.Z., Claro, I., Santos, D.W., de Jesus, J.G., Ferreira, N.E., Romano, C.M., et al. (2020). First case of SARS-COV-2 sequencing in cerebrospinal fluid of a patient with suspected demyelinating disease. J. Neurol. 267: 3154-3156.

Dörries, R., Watanabe, R., Wege, H., and ter Meulen, V. (1986). Murine coronavirus-induced encephalomyelitis in rats: analysis of immunoglobulins and virus-specific antibodies in serum and cerebrospinal fluid. J. Neuroimmunol. 12: 131-142.

DosSantos, M.F., Devalle, S., Aran, V., Capra, D., Roque, N.R., CoelhoAguiar, J.d. M., Spohr, T.C.L.d. S.E., Subilhaga, J.G., Pereira, C.M., D'Andrea Meira, I., et al. (2020). Neuromechanisms of SARS-CoV-2: a review. Front. Neuroanat. 14, 37.

Durham, P.J., Stevenson, B.J., and Farquharson, B.C. (1979). Rotavirus and coronavirus associated diarrhoea in domestic animals. N. Z. Vet. J. 27: 30-32.

Ebers, G.C. and Sadovnick, A.D. (1994). The role of genetic factors in multiple sclerosis susceptibility. J. Neuroimmunol. 54: 1-17.

Edwards, S., Zvartau, M., Clarke, H., Irving, W., and Blumhardt, L.D. (1998). Clinical relapses and disease activity on magnetic resonance imaging associated with viral upper respiratory tract infections in multiple sclerosis. J. Neurol. Neurosurg. Psychiatry 64: 736-741.

Ehrenfeld, M., Tincani, A., Andreoli, L., Cattalini, M., Greenbaum, A., Kanduc, D., Alijotas-Reig, J., Zinserling, V., Semenova, N., Amital, H., et al. (2020). Covid-19 and autoimmunity. Autoimmun. Rev. 19: 102597.

Elavarasi, A., Srivastava, V.P., and Garg, A. (2021). COVID-19-Related multifocal demyelinating neuropathy: causation or association. Cureus 13: e17770.

Elian, M., Nightingale, S., and Dean, G. (1990). Multiple sclerosis among United Kingdom-born children of immigrants from the Indian subcontinent, Africa and the West Indies. J. Neurol. Neurosurg. Psychiatry 53: 906-911.

Espíndola, O.M., Brandão, C.O., Gomes, Y.C.P., Siqueira, M., Soares, C.N., Lima, M., Leite, A., Torezani, G., Araujo, A.Q.C., and Silva, M.T.T. (2020). Cerebrospinal fluid findings in neurological diseases associated with COVID-19 and insights into mechanisms of disease development. Int. J. Infect. Dis. 102: 155-162.

Fleming, J.O., el Zaatari, F.A., Gilmore, W., Berne, J.D., Burks, J.S., Stohlman, S.A., Tourtellotte, W.W., and Weiner, L.P. (1988). Antigenic assessment of coronaviruses isolated from patients with multiple sclerosis. Arch. Neurol. 45: 629-633.

Fleming, J.O., Stohlman, S.A., and Weiner, L.P. (1982). Coronaviruses and multiple sclerosis. Arch. Neurol. 39: 455.

Fleming, J.O., Ting, J.Y., Stohlman, S.A., and Weiner, L.P. (1983). Improvements in obtaining and characterizing mouse cerebrospinal fluid. Application to mouse hepatitis virusinduced encephalomyelitis. J. Neuroimmunol. 4: 129-140.

Florea, A.A., Sirbu, C.A., Ghinescu, M.C., Plesa, C.F., Sirbu, A.M., Mitrica, M., and lonita-Radu, F. (2021). SARS-CoV-2, multiple sclerosis, and focal deficit in a postpartum woman: a case report. Exp. Ther. Med. 21: 92.

Franke, C., Ferse, C., Kreye, J., Reincke, S.M., Sanchez-Sendin, E., Rocco, A., Steinbrenner, M., Angermair, S., Treskatsch, S., Zickler, D., et al. (2021). High frequency of cerebrospinal fluid autoantibodies in COVID-19 patients with neurological symptoms. Brain Behav. Immun. 93: 415-419.

Fraussen, J., Claes, N., de Bock, L., and Somers, V. (2014). Targets of the humoral autoimmune response in multiple sclerosis. Autoimmun. Rev. 13: 1126-1137.

Fu, Y., Cheng, Y., and Wu, Y. (2020). Understanding SARS-CoV2-mediated inflammatory responses: from mechanisms to potential therapeutic tools. Virol. Sin. 35: 266-271.

Fuchs, V., Kutza, M., Wischnewski, S., Deigendesch, N., Lutz, L., Kulsvehagen, L., Ricken, G., Kappos, L., Tzankov, A., Hametner, S., et al. (2021). Presence of SARS-CoV-2 transcripts in the choroid plexus of MS and non-MS patients with COVID-19. Neurol. Neuroimmunol. Neuroinflamm 8: e957.

Fujinami, R.S. and Oldstone, M.B. (1985). Amino acid homology between the encephalitogenic site of myelin basic protein and virus: mechanism for autoimmunity. Science 230: 1043-1045.

Fujinami, R.S., von Herrath, M.G., Christen, U., and Whitton, J.L. (2006). Molecular mimicry, bystander activation, or viral persistence: infections and autoimmune disease. Clin. Microbiol. Rev. 19: 80-94.

Galeotti, C. and Bayry, J. (2020). Autoimmune and inflammatory diseases following COVID-19. Nat. Rev. Rheumatol. 16: 413-414.

Garg, R.K., Mahadevan, A., Malhotra, H.S., Rizvi, I., Kumar, N., and Uniyal, R. (2019). Subacute sclerosing panencephalitis. Rev. Med. Virol. 29: e2058.

Garren, H., Steinman, L., and Lock, C. (1998). The specificity of the antibody response in multiple sclerosis. Ann. Neurol. 43: 4-6.

Gkoutzourelas, A., Bogdanos, D.P., and Sakkas, L.I. (2020). Kawasaki disease and COVID-19. Mediterr J Rheumatol 31: 268-274.

Gonzales, D.M., Fu, L., Li, Y., Das Sarma, J., and Lavi, E. (2004). Coronavirus-induced demyelination occurs in the absence of CD28 costimulatory signals. J. Neuroimmunol. 146: 140-143.

Grigoriadis, N., Grigoriadis, S., Polyzoidou, E., Milonas, I., and Karussis, D. (2006). Neuroinflammation in multiple sclerosis: evidence for autoimmune dysregulation, not simple autoimmune reaction. Clin. Neurol. Neurosurg. 108: 241-244.

Grigoriadis, N. and Hadjigeorgiou, G.M. (2006). Virus-mediated autoimmunity in multiple sclerosis. J. Autoimmune Dis. 3: 1.

Grigoriadis, N., van Pesch, V., and Paradig, M.S.G. (2015). A basic overview of multiple sclerosis immunopathology. Eur. J. Neurol. 22: 3-13.

Gu, J., Gong, E., Zhang, B., Zheng, J., Gao, Z., Zhong, Y., Zou, W., Zhan, J., Wang, S., Xie, Z., et al. (2005). Multiple organ infection and the pathogenesis of SARS. J. Exp. Med. 202: 415-424.

Gutiérrez-Ortiz, C., Méndez-Guerrero, A., Rodrigo-Rey, S., San Pedro-Murillo, E., Bermejo-Guerrero, L., Gordo-Mañas, R., de Aragón-Gómez, F., and Benito-León, J. (2020). Miller Fisher syndrome and polyneuritis cranialis in COVID-19. Neurology 95: e601-e605.

Hadjigeorgiou, G.M., Kountra, P.M., Koutsis, G., Tsimourtou, V., Siokas, V., Dardioti, M., Rikos, D., Marogianni, C., Aloizou, A.M., 
Karadima, G., et al. (2019). Replication study of GWAS risk loci in Greek multiple sclerosis patients. Neurol. Sci. 40: 253-260.

Haider, L., Simeonidou, C., Steinberger, G., Hametner, S., Grigoriadis, N., Deretzi, G., Kovacs, G.G., Kutzelnigg, A., Lassmann, H., and Frischer, J.M. (2014). Multiple sclerosis deep grey matter: the relation between demyelination, neurodegeneration, inflammation and iron. J. Neurol. Neurosurg. Psychiatry 85: 1386-1395.

Halpert, G. and Shoenfeld, Y. (2020). SARS-CoV-2, the autoimmune virus. Autoimmun. Rev. 19: 102695.

Haring, J.S., Pewe, L.L., and Perlman, S. (2002). Bystander CD8 T cellmediated demyelination after viral infection of the central nervous system. J. Immunol. 169: 1550-1555.

Haubold, K., Owens, G.P., Kaur, P., Ritchie, A.M., Gilden, D.H., and Bennett, J.L. (2004). B-lymphocyte and plasma cell clonal expansion in monosymptomatic optic neuritis cerebrospinal fluid. Ann. Neurol. 56: 97-107.

Hemmer, B., Nessler, S., Zhou, D., Kieseier, B., and Hartung, H.P. (2006). Immunopathogenesis and immunotherapy of multiple sclerosis. Nat. Clin. Pract. Neurol. 2: 201-211.

Herndon, R.M., Griffin, D.E., McCormick, U., and Weiner, L.P. (1975). Mouse hepatitis virus-induced recurrent demyelination. A preliminary report. Arch. Neurol. 32: 32-35.

Houtman, J.J. and Fleming, J.O. (1996). Dissociation of demyelination and viral clearance in congenitally immunodeficient mice infected with murine coronavirus JHM. J. Neurovirol. 2: 101-110.

Hovanec, D.L. and Flanagan, T.D. (1983). Detection of antibodies to human coronaviruses $229 \mathrm{E}$ and OC43 in the sera of multiple sclerosis patients and normal subjects. Infect. Immun. 41: 426-429.

Ismail and Salama, S. (2022). Association of CNS demyelination and COVID-19 infection: an updated systematic review. J. Neurol. 269: 541-576.

Jacomy, H., St-Jean, J.R., Brison, E., Marceau, G., Desforges, M., and Talbot, P.J. (2010). Mutations in the spike glycoprotein of human coronavirus OC43 modulate disease in BALB/c mice from encephalitis to flaccid paralysis and demyelination. J. Neurovirol. 16: 279-293.

Jacomy, H. and Talbot, P.J. (2003). Vacuolating encephalitis in mice infected by human coronavirus OC43. Virology 315: 20-33.

Jaquiéry, E., Jilek, S., Schluep, M., Meylan, P., Lysandropoulos, A., Pantaleo, G., and Du Pasquier, R.A. (2010). Intrathecal immune responses to EBV in early MS. Eur. J. Immunol. 40: 878-887.

Johnson, R.T. (1994). The virology of demyelinating diseases. Ann. Neurol. 36: S54-S60.

Jordan, C.A., Friedrich, V.L., Jr., Godfraind, C., Cardellechio, C.B., Holmes, K.V., and Dubois-Dalcq, M. (1989). Expression of viral and myelin gene transcripts in a murine CNS demyelinating disease caused by a coronavirus. Glia 2: 318-329.

Juliao Caamaño, D.S. and Alonso Beato, R. (2020). Facial diplegia, a possible atypical variant of Guillain-Barré Syndrome as a rare neurological complication of SARS-CoV-2. J. Clin. Neurosci. 77: 230-232.

Kabat, E.A., Freedman, D.A.. (1950). A study of the crystalline albumin, gamma globulin and total protein in the cerebrospinal fluid of 100 cases of multiple sclerosis and in other diseases. Am. J. Med. Sci. 219: 55-64.

Karapanayiotides, T., Geka, E., Prassopoulos, P., Koutroulou, I., Kollaras, P., Kiourtzieva, E., Pourzitaki, C., Veroniki, F., Sintila, S.A., Astreinidis, A., et al. (2020). Concentric demyelination pattern in COVID-19-associated acute haemorrhagic leukoencephalitis: a lurking catastrophe? Brain 143: e100.

Karsidag, S., Sahin, S., Ates, M.F., Cinar, N., and Kendirli, S. (2021). Demyelinating disease of the central nervous system concurrent with COVID-19. Cureus 13: e17297.

Kawanokuchi, J., Shimizu, K., Nitta, A., Yamada, K., Mizuno, T., Takeuchi, H., and Suzumura, A. (2008). Production and functions of IL-17 in microglia. J. Neuroimmunol. 194: 54-61.

Keegan, B.M. and Noseworthy, J.H. (2002). Multiple sclerosis. Annu. Rev. Med. 53: 285-302.

Khandelwal, K., Puranik, M., Gupta, V., Khandelwal, G., Dave, P.K., and Hirve, M. (2021). COVID-19 associated acute demyelination masquerading as stroke: a case report. Egypt. J. Radiol. Nucl. Med. 52: 32.

Kim, J.E., Heo, J.H., Kim, H.O., Song, S.H., Park, S.S., Park, T.H., Ahn, J.Y., Kim, M.K., and Choi, J.P. (2017). Neurological complications during treatment of Middle East respiratory syndrome. J. Clin. Neurol. 13: 227-233.

Klein, R.S., Garber, C., and Howard, N. (2017). Infectious immunity in the central nervous system and brain function. Nat. Immunol. 18: 132-141.

Knobler, R.L., Taylor, B.A., Wooddell, M.K., Beamer, W.G., and Oldstone, M.B. (1984). Host genetic control of mouse hepatitis virus type-4 (JHM strain) replication. II. The gene locus for susceptibility is linked to the Svp-2 locus on mouse chromosome 7. Exp. Clin. Immunogenet. 1: 217-222.

Kohm, A.P., Fuller, K.G., and Miller, S.D. (2003). Mimicking the way to autoimmunity: an evolving theory of sequence and structural homology. Trends Microbiol. 11: 101-105.

Koutsouraki, E., Costa, V., and Baloyannis, S. (2010). Epidemiology of multiple sclerosis in Europe: a review. Int. Rev. Psychiatr. 22: 2-13.

Kurtzke, J.F. (1993). Epidemiologic evidence for multiple sclerosis as an infection. Clin. Microbiol. Rev. 6: 382-427.

Kurtzke, J.F. and Hyllested, K. (1979). Multiple sclerosis in the Faroe Islands: I. Clinical and epidemiological features. Ann. Neurol. 5: 6-21.

Kyuwa, S., Yamaguchi, K., Toyoda, Y., and Fujiwara, K. (1991). Induction of self-reactive T cells after murine coronavirus infection. J. Virol. 65: 1789-1795.

Lai, M.M. and Cavanagh, D. (1997). The molecular biology of coronaviruses. Adv. Virus Res. 48: 1-100.

Lalchhandama, K. (2020). The chronicles of coronaviruses: the bronchitis, the hepatitis and the common cold. Sci. Vis. 20: 43-53.

Lampert, P.W., Sims, J.K., and Kniazeff, A.J. (1973). Mechanism of demyelination in JHM virus encephalomyelitis. Electron microscopic studies. Acta Neuropathol. 24: 76-85.

Lane, T.E. and Hosking, M.P. (2010). The pathogenesis of murine coronavirus infection of the central nervous system. Crit. Rev. Immunol. 30: 119-130.

Lassmann, H. (2014). Mechanisms of white matter damage in multiple sclerosis. Glia 62: 1816-1830.

Lau, K.K., Yu, W.C., Chu, C.M., Lau, S.T., Sheng, B., and Yuen, K.Y. (2004). Possible central nervous system infection by SARS coronavirus. Emerg. Infect. Dis. 10: 342-344.

Lavi, E., Gilden, D.H., Wroblewska, Z., Rorke, L.B., and Weiss, S.R. (1984). Experimental demyelination produced by the A59 strain of mouse hepatitis virus. Neurology 34, 597. 
Lavi, E., Schwartz, T., Jin, Y.P., and Fu, L. (1999). Nidovirus infections: experimental model systems of human neurologic diseases. J. Neuropathol. Exp. Neurol. 58: 1197-1206.

Levin, M.C., Lee, S., Gardner, L.A., Shin, Y., Douglas, J.N., and Cooper, C. (2013). Autoantibodies to non-myelin antigens as contributors to the pathogenesis of multiple sclerosis. J. Clin. Cell. Immunol. 4, https://doi.org/10.4172/2155-9899.1000148.

Li, Y., Fu, L., Gonzales, D.M., and Lavi, E. (2004). Coronavirus neurovirulence correlates with the ability of the virus to induce proinflammatory cytokine signals from astrocytes and microglia. J. Virol. 78: 3398-3406.

Lima, M., Siokas, V., Aloizou, A.M., Liampas, I., Mentis, A.A., Tsouris, Z., Papadimitriou, A., Mitsias, P.D., Tsatsakis, A., Bogdanos, D.P., et al. (2020). Unraveling the possible routes of SARS-COV-2 invasion into the central nervous system. Curr. Treat. Options Neurol. 22: 37.

Liu, Y., Sawalha, A.H., and Lu, Q. (2021). COVID-19 and autoimmune diseases. Curr. Opin. Rheumatol. 33: 155-162.

Lobo, A.P., Cardoso-Dos-Santos, A.C., Rocha, M.S., Pinheiro, R.S., Bremm, J.M., Macário, E.M., Oliveira, W.K., and França, G.V.A. (2020). COVID-19 epidemic in Brazil: where are we at? Int. J. Infect. Dis. 97: 382-385.

Lossius, A., Johansen, J.N., Vartdal, F., Robins, H., Jūratė Šaltytė, B., Holmøy, T., and Olweus, J. (2014). High-throughput sequencing of TCR repertoires in multiple sclerosis reveals intrathecal enrichment of EBV-reactive CD8+ T cells. Eur. J. Immunol. 44: 3439-3452.

Low, R.N., Low, R.J., and Akrami, A. (2020). A Cytokine-based model for the pathophysiology of Long COVID symptoms. OSF Preprints.

Lu, R., Zhao, X., Li, J., Niu, P., Yang, B., Wu, H., Wang, W., Song, H., Huang, B., Zhu, N., et al. (2020). Genomic characterisation and epidemiology of 2019 novel coronavirus: implications for virus origins and receptor binding. Lancet 395: 565-574.

Lucchinetti, C., Brück, W., Parisi, J., Scheithauer, B., Rodriguez, M., and Lassmann, H. (2000). Heterogeneity of multiple sclerosis lesions: implications for the pathogenesis of demyelination. Ann. Neurol. 47: 707-717.

Madden, D.L., Wallen, W.C., Houff, S.A., Leinikki, P.A., Sever, J.L., Holmes, K.A., Castellano, G.A., and Shekarchi, I.C. (1981). Coronavirus antibodies in sera from patients with multiple sclerosis and matched controls. Arch. Neurol. 38: 209-210.

Magliozzi, R., Howell, O., Vora, A., Serafini, B., Nicholas, R., Puopolo, M., Reynolds, R., and Aloisi, F. (2007). Meningeal B-cell follicles in secondary progressive multiple sclerosis associate with early onset of disease and severe cortical pathology. Brain 130: 1089-1104.

Mailand, M.T. and Frederiksen, J.L. (2017). Vaccines and multiple sclerosis: a systematic review. J. Neurol. 264: 1035-1050.

Marrodan, M., Alessandro, L., Farez, M.F., and Correale, J. (2019). The role of infections in multiple sclerosis. Mult. Scler. 25: 891-901.

Matschke, J., Lütgehetmann, M., Hagel, C., Sperhake, J.P., Schröder, A.S., Edler, C., Mushumba, H., Fitzek, A., Allweiss, L., Dandri, M., et al. (2020). Neuropathology of patients with COVID-19 in Germany: a post-mortem case series. Lancet Neurol. 19: 919-929.

Mehta, P., McAuley, D.F., Brown, M., Sanchez, E., Tattersall, R.S., and Manson, J.J. (2020). COVID-19: consider cytokine storm syndromes and immunosuppression. Lancet 395: 1033-1034.

Melo, C.M.L., Silva, G.A.S., Melo, A.R.S., and Freitas, A.C. (2020). COVID-19 pandemic outbreak: the Brazilian reality from the first case to the collapse of health services. An. Acad. Bras. Cienc. 92: e20200709.

Mendelman, P.M., Jankovsky, L.D., Murray, R.S., Licari, P., DeVald, B., Gerdes, J.C., and Burks, J.S. (1983). Pathogenesis of coronavirus SD in mice. I. Prominent demyelination in the absence of infectious virus production. Arch. Neurol. 40: 493-498.

Menge, T., Hemmer, B., Nessler, S., Wiendl, H., Neuhaus, O., Hartung, H.P., Kieseier, B.C., and Stüve, O. (2005). Acute disseminated encephalomyelitis: an update. Arch. Neurol. 62: 1673-1680.

Mentis, A.A., Dardiotis, E., Grigoriadis, N., Petinaki, E., and Hadjigeorgiou, G.M. (2017). Viruses and endogenous retroviruses in multiple sclerosis: from correlation to causation. Acta Neurol. Scand. 136: 606-616.

Mesel-Lemoine, M., Millet, J., Vidalain, P.O., Law, H., Vabret, A., Lorin, V., Escriou, N., Albert, M.L., Nal, B., and Tangy, F. (2012). A human coronavirus responsible for the common cold massively kills dendritic cells but not monocytes. J. Virol. 86: 7577-7587.

Meshkat, S., Salimi, A., Joshaghanian, A., Sedighi, S., Sedighi, S., and Aghamollaii, V. (2020). Chronic neurological diseases and COVID-19: associations and considerations. Transl. Neurosci. 11: 294-301.

Morgello, S. (2018). HIV neuropathology. Handb. Clin. Neurol. 152: 3-19.

Moriguchi, T., Harii, N., Goto, J., Harada, D., Sugawara, H., Takamino, J., Ueno, M., Sakata, H., Kondo, K., Myose, N., et al. (2020). A first case of meningitis/encephalitis associated with SARS-Coronavirus-2. Int. J. Infect. Dis. 94: 55-58.

Multiple sclerosis genomic map implicates peripheral immune cells and microglia in susceptibility (2019). Science 365.

Murphy, A.C., Lalor, S.J., Lynch, M.A., and Mills, K.H. (2010). Infiltration of Th1 and Th17 cells and activation of microglia in the CNS during the course of experimental autoimmune encephalomyelitis. Brain Behav. Immun. 24: 641-651.

Murray, R.S., Brown, B., Brian, D., and Cabirac, G.F. (1992a). Detection of coronavirus RNA and antigen in multiple sclerosis brain. Ann. Neurol. 31: 525-533.

Murray, R.S., Cai, G.Y., Hoel, K., Johnson, S., and Cabirac, G.F. (1993). Coronaviruses and multiple sclerosis. Adv. Exp. Med. Biol. 342: 353-357.

Murray, R.S., Cai, G.Y., Hoel, K., Zhang, J.Y., Soike, K.F., and Cabirac, G.F. (1992b). Coronavirus infects and causes demyelination in primate central nervous system. Virology 188: 274-284.

Nagashima, K., Wege, H., Meyermann, R., and ter Meulen, V. (1978). Corona virus induced subacute demyelinating encephalomyelitis in rats: a morphological analysis. Acta Neuropathol. 44: 63-70.

Neumann, B., Schmidbauer, M.L., Dimitriadis, K., Otto, S., Knier, B., Niesen, W.D., Hosp, J.A., Günther, A., Lindemann, S., Nagy, G., et al. (2020). Cerebrospinal fluid findings in COVID-19 patients with neurological symptoms. J. Neurol. Sci. 418: 117090.

Novi, G., Rossi, T., Pedemonte, E., Saitta, L., Rolla, C., Roccatagliata, L., Inglese, M., and Farinini, D. (2020). Acute disseminated encephalomyelitis after SARS-CoV-2 infection. Neurol. Neuroimmunol. Neuroinflamm 7: 5.

Olson, J.K., Croxford, J.L., Calenoff, M.A., Dal Canto, M.C., and Miller, S.D. (2001). A virus-induced molecular mimicry model of multiple sclerosis. J. Clin. Invest. 108: 311-318.

Ottaviani, D., Boso, F., Tranquillini, E., Gapeni, I., Pedrotti, G., Cozzio, S., Guarrera, G.M., and Giometto, B. (2020). Early Guillain-Barré 
syndrome in coronavirus disease 2019 (COVID-19): a case report from an Italian COVID-hospital. Neurol. Sci. 41: 1351-1354.

Owens, G.P., Gilden, D., Burgoon, M.P., Yu, X., and Bennett, J.L. (2011). Viruses and multiple sclerosis. Neuroscientist 17: 659-676.

Oxley, T.J., Mocco, J., Majidi, S., Kellner, C.P., Shoirah, H., Singh, I.P., De Leacy, R.A., Shigematsu, T., Ladner, T.R., Yaeger, K.A., et al. (2020). Large-vessel stroke as a presenting feature of covid-19 in the young. N. Engl. J. Med. 382: e60.

Palanichamy, A., Apeltsin, L., Kuo, T.C., Sirota, M., Wang, S., Pitts, S.J., Sundar, P.D., Telman, D., Zhao, L.Z., Derstine, M., et al. (2014). Immunoglobulin class-switched $B$ cells form an active immune axis between CNS and periphery in multiple sclerosis. Sci. Transl. Med. 6, 248ra106, https://doi.org/10.1126/ scitranslmed.3008930.

Palao, M., Fernández-Díaz, E., Gracia-Gil, J., Romero-Sánchez, C.M., Díaz-Maroto, I., and Segura, T. (2020). Multiple sclerosis following SARS-CoV-2 infection. Mult Scler Relat Disord 45: 102377.

Pappenheimer, A.M. (1958). Pathology of infection with the JHM virus. J. Natl. Cancer Inst. 20: 879-891.

Parsons, T., Banks, S., Bae, C., Gelber, J., Alahmadi, H., and Tichauer, M. (2020). COVID-19-associated acute disseminated encephalomyelitis (ADEM). J. Neurol. 267: 2799-2802.

Paterson, R.W., Brown, R.L., Benjamin, L., Nortley, R., Wiethoff, S., Bharucha, T., Jayaseelan, D.L., Kumar, G., Raftopoulos, R.E., Zambreanu, L., et al. (2020). The emerging spectrum of COVID-19 neurology: clinical, radiological and laboratory findings. Brain 143: 3104-3120.

Paules, C.I., Marston, H.D., and Fauci, A.S. (2020). Coronavirus infections-more than just the common cold. JAMA 323: 707-708.

Peterson, L.K. and Fujinami, R.S. (2007). Inflammation, demyelination, neurodegeneration and neuroprotection in the pathogenesis of multiple sclerosis. J. Neuroimmunol. 184: 37-44.

Porter, K.G., Sinnamon, D.G., and Gillies, R.R. (1977). Cryptococcus neoformans-specific oligoclonal immunoglobulins in cerebrospinal fluid in cryptococcal meningitis. Lancet 1: 1262.

Qin, Y., Duquette, P., Zhang, Y., Olek, M., Da, R.R., Richardson, J., Antel, J.P., Talbot, P., Cashman, N.R., Tourtellotte, W.W., et al. (2003). Intrathecal B-cell clonal expansion, an early sign of humoral immunity, in the cerebrospinal fluid of patients with clinically isolated syndrome suggestive of multiple sclerosis. Lab. Invest. 83: 1081-1088.

Rabaan, A.A., Al-Ahmed, S.H., Haque, S., Sah, R., Tiwari, R., Malik, Y.S., Dhama, K., Yatoo, M.I., Bonilla-Aldana, D.K., and Rodriguez-Morales, A.J. (2020). SARS-CoV-2, SARS-CoV, and MERS-COV: a comparative overview. Inf. Med. 28: 174-184.

Rangachari, M. and Kuchroo, V.K. (2013). Using EAE to better understand principles of immune function and autoimmune pathology. J. Autoimmun. 45: 31-39.

Reichard, R.R., Kashani, K.B., Boire, N.A., Constantopoulos, E., Guo, Y., and Lucchinetti, C.F. (2020). Neuropathology of COVID-19: a spectrum of vascular and acute disseminated encephalomyelitis (ADEM)-like pathology. Acta Neuropathol. 140: 1-6.

Reindl, M., Kuenz, B., and Berger, T. (2010). B cells and antibodies in MS. Results Probl. Cell Differ. 51: 99-113.

Sadovnick, A.D., Armstrong, H., Rice, G.P., Bulman, D., Hashimoto, L., Paty, D.W., Hashimoto, S.A., Warren, S., Hader, W., Murray, T.J., et al (1993). A population-based study of multiple sclerosis in twins: update. Ann. Neurol. 33: 281-285.

Salmi, A., Ziola, B., Hovi, T., and Reunanen, M. (1982). Antibodies to coronaviruses OC43 and 229E in multiple sclerosis patients. Neurology 32: 292-295.

Schiffenbauer, J., Johnson, H.M., Butfiloski, E.J., Wegrzyn, L., and Soos, J.M. (1993). Staphylococcal enterotoxins can reactivate experimental allergic encephalomyelitis. Proc. Natl. Acad. Sci. U. S. A. 90: 8543-8546.

Schochetman, G., Stevens, R.H., and Simpson, R.W. (1977). Presence of infectious polyadenylated RNA in coronavirus avian bronchitis virus. Virology 77: 772-782.

Serafini, B., Rosicarelli, B., Magliozzi, R., Stigliano, E., and Aloisi, F. (2004). Detection of ectopic B-cell follicles with germinal centers in the meninges of patients with secondary progressive multiple sclerosis. Brain Pathol. 14: 164-174.

Serrano, G.E., Walker, J.E., Arce, R., Glass, M.J., Vargas, D., Sue, L.I., Intorcia, A.J., Nelson, C.M., Oliver, J., Papa, J., et al. (2021). Mapping of SARS-CoV-2 brain invasion and histopathology in COVID-19 disease. medRxiv, 2021.2002.2015.21251511.

Sfriso, P., Ghirardello, A., Botsios, C., Tonon, M., Zen, M., Bassi, N., Bassetto, F., and Doria, A. (2010). Infections and autoimmunity: the multifaceted relationship. J. Leukoc. Biol. 87: 385-395.

Sibley, W.A., Bamford, C.R., and Clark, K. (1985). Clinical viral infections and multiple sclerosis. Lancet 1: 1313-1315.

Siokas, V., Katsiardanis, K., Aloizou, A.M., Bakirtzis, C., Liampas, I., Koutlas, E., Rudolf, J., Ntinoulis, K., Kountouras, J., Dardiotis, E., et al. (2021). Impact of body mass index on the age of relapsingremitting multiple sclerosis onset: a retrospective study. Neurol. Int. 13: 517-526.

Siokas, V., Tsouris, Z., Aloizou, A.M., Bakirtzis, C., Liampas, I., Koutsis, G., Anagnostouli, M., Bogdanos, D.P., Grigoriadis, N., Hadjigeorgiou, G.M., et al. (2020). Multiple sclerosis: shall we target CD33? Genes 11: 11.

Sokratous, M., Dardiotis, E., Bellou, E., Tsouris, Z., Michalopoulou, A., Dardioti, M., Siokas, V., Rikos, D., Tsatsakis, A., Kovatsi, L., et al. (2018). CpG island methylation patterns in relapsing-remitting multiple sclerosis. J. Mol. Neurosci. 64: 478-484.

Sokratous, M., Dardiotis, E., Tsouris, Z., Bellou, E., Michalopoulou, A., Siokas, V., Arseniou, S., Stamati, T., Tsivgoulis, G., Bogdanos, D., et al. (2016). Deciphering the role of DNA methylation in multiple sclerosis: emerging issues. Auto Immun Highlights 7: 12.

Soldan, S.S. and Jacobson, S. (2001). Role of viruses in etiology and pathogenesis of multiple sclerosis. Adv. Virus Res. 56: 517-555.

Sospedra, M. and Martin, R. (2005). Immunology of multiple sclerosis. Annu. Rev. Immunol. 23: 683-747.

Sotelo, J., Martínez-Palomo, A., Ordoñez, G., and Pineda, B. (2008). Varicella-zoster virus in cerebrospinal fluid at relapses of multiple sclerosis. Ann. Neurol. 63: 303-311.

Spielman, R.S. and Nathanson, N. (1982). The genetics of susceptibility to multiple sclerosis. Epidemiol. Rev. 4: 45-65.

Steinman, L. (2001). Multiple sclerosis: a two-stage disease. Nat. Immunol. 2: 762-764.

Stern, J.N., Yaari, G., Vander Heiden, J.A., Church, G., Donahue, W.F., Hintzen, R.Q., Huttner, A.J., Laman, J.D., Nagra, R.M., Nylander, A., et al. (2014). B cells populating the multiple sclerosis brain mature in the draining cervical lymph nodes. Sci. Transl. Med. 6, 248 ra107. 
Stewart, J.N., Mounir, S., and Talbot, P.J. (1992). Human coronavirus gene expression in the brains of multiple sclerosis patients. Virology 191: 502-505.

Stohlman, S.A. and Frelinger, J.A. (1978). Resistance to fatal central nervous system disease by mouse hepatitis virus, strain JHM: I. Genetic analysis. Immunogenetics 6: 277-281.

Stohlman, S.A. and Weiner, L.P. (1981). Chronic central nervous system demyelination in mice after JHM virus infection. Neurology 31: 38.

Strachan-Whaley, M., Rivest, S., and Yong, V.W. (2014). Interactions between microglia and T cells in multiple sclerosis pathobiology. J. Interferon Cytokine Res. 34: 615-622.

Su, S., Wong, G., Shi, W., Liu, J., Lai, A.C.K., Zhou, J., Liu, W., Bi, Y., and Gao, G.F. (2016). Epidemiology, genetic recombination, and pathogenesis of coronaviruses. Trends Microbiol. 24: 490-502.

Swanborg, R.H. (1988). Experimental allergic encephalomyelitis. Methods Enzymol. 162: 413-421.

Talbot, H.K. and Falsey, A.R. (2010). The diagnosis of viral respiratory disease in older adults. Clin. Infect. Dis. 50: 747-751.

Talbot, P.J., Paquette, J.S., Ciurli, C., Antel, J.P., and Ouellet, F. (1996). Myelin basic protein and human coronavirus $229 \mathrm{E}$ cross-reactive T cells in multiple sclerosis. Ann. Neurol. 39: 233-240.

Tanaka, R., Iwasaki, Y., and Koprowski, H. (1976). Intracisternal viruslike particles in brain of a multiple sclerosis patient. J. Neurol. Sci. 28: 121-126.

Terruzzi, S., Chiusole, M., Ottaviani, D., Rozzanigo, U., and Papagno, C. (2021). A case of anterograde amnesia in an MS-like demyelination after COVID-19. Neurol. Sci. 1-6, https://doi.org/ 10.1007/s10072-021-05665-6.

Toscano, G., Palmerini, F., Ravaglia, S., Ruiz, L., Invernizzi, P., Cuzzoni, M.G., Franciotta, D., Baldanti, F., Daturi, R., Postorino, P., et al. (2020). Guillain-barré syndrome associated with SARS-CoV-2. N. Engl. J. Med. 382: 2574-2576.

Tsai, L.K., Hsieh, S.T., and Chang, Y.C. (2005). Neurological manifestations in severe acute respiratory syndrome. Acta Neurol. Taiwan 14: 113-119.

Tselis, A. (2011). Evidence for viral etiology of multiple sclerosis. Semin. Neurol. 31: 307-316.

Tuohy, V.K., Yu, M., Weinstock-Guttman, B., and Kinkel, R.P. (1997). Diversity and plasticity of self recognition during the development of multiple sclerosis. J. Clin. Invest. 99: 1682-1690.

Tyrrell, D.A., Almeida, J.D., Cunningham, C.H., Dowdle, W.R., Hofstad, M.S., McIntosh, K., Tajima, M., Zakstelskaya, L.Y., Easterday, B.C., Kapikian, A., et al. (1975). Coronaviridae. Intervirology. 5: 76-82.

Tyrrell, D.A. and Bynoe, M.L. (1965). Cultivation of a novel type of common-cold virus in organ cultures. Br. Med. J. 1: 1467-1470.

Vandvik, B., Norrby, E., Nordal, H.J., and Degré, M. (1976). Oligoclonal measles virus-specific IgG antibodies isolated from cerebrospinal fluids, brain extracts, and sera from patients with subacute sclerosing panencephalitis and multiple sclerosis. Scand. J. Immunol. 5: 979-992.

Vartdal, F., Vandvik, B., Michaelsen, T.E., Loe, K., and Norrby, E. (1982). Neurosyphilis: intrathecal synthesis of oligoclonal antibodies to Treponema pallidum. Ann. Neurol. 11: 35-40.

Virtanen, J.O. and Jacobson, S. (2012). Viruses and multiple sclerosis. CNS Neurol. Disord. - Drug Targets 11: 528-544.

Vojdani, A. and Kharrazian, D. (2020). Potential antigenic crossreactivity between SARS-CoV-2 and human tissue with a possible link to an increase in autoimmune diseases. Clin. Immunol. 217: 108480.

von Büdingen, H.C., Gulati, M., Kuenzle, S., Fischer, K., Rupprecht, T.A., and Goebels, N. (2010). Clonally expanded plasma cells in the cerebrospinal fluid of patients with central nervous system autoimmune demyelination produce "oligoclonal bands. J. Neuroimmunol. 218: 134-139.

Wallin, M.T., Culpepper, W.J., Campbell, J.D., Nelson, L.M., LangerGould, A., Marrie, R.A., Cutter, G.R., Kaye, W.E., Wagner, L., Tremlett, H., et al. (2019). The prevalence of MS in the United States: a population-based estimate using health claims data. Neurology 92: e1029-e1040.

Wang, J.Y., Zhang, W., Roehrl, M.W., Roehrl, V.B., and Roehrl, M.H. (2021). An autoantigen atlas from human lung HFL1 cells offers clues to neurological and diverse autoimmune manifestations of COVID-19. bioRxiv, 2021.2001.2024.427965.

Watanabe, R., Wege, H., and Ter Meulen, V. (1983). Adoptive transfer of EAE-like lesions from rats with coronavirus-induced demyelinating encephalomyelitis. Nature 305: 150-153.

Wege, H., Koga, M., Watanabe, R., Nagashima, K., and ter Meulen, V. (1983). Neurovirulence of murine coronavirus JHM temperaturesensitive mutants in rats. Infect. Immun. 39: 1316-1324.

Weiner, L.P. (1973). Pathogenesis of demyelination induced by a mouse hepatitis. Arch. Neurol. 28: 298-303.

Weiss, S.R. and Navas-Martin, S. (2005). Coronavirus pathogenesis and the emerging pathogen severe acute respiratory syndrome coronavirus. Microbiol. Mol. Biol. Rev. 69: 635-664.

Wentworth, D.E., Tresnan, D.B., Turner, B.C., Lerman, I.R., Bullis, B., Hemmila, E.M., Levis, R., Shapiro, L.H., and Holmes, K.V. (2005). Cells of human aminopeptidase N (CD13) transgenic mice are infected by human coronavirus-229E in vitro, but not in vivo. Virology 335: 185-197.

Wood, H. (2017). Multiple sclerosis: latitude and vitamin D influence disease course in multiple sclerosis. Nat. Rev. Neurol. 13: 3.

Wroblewska, Z., Gilden, D., Devlin, M., Huang, E.S., Rorke, L.B., Hamada, T., Furukawa, T., Cummins, L., Kalter, S., and Koprowski, H. (1979). Cytomegalovirus isolation from a chimpanzee with acute demyelinating disease after inoculation of multiple sclerosis brain cells. Infect. Immun. 25: 1008-1015.

Wu, G.F., Pewe, L., and Perlman, S. (2000). Coronavirus-induced demyelination occurs in the absence of inducible nitric oxide synthase. J. Virol. 74: 7683-7686.

Wu, Y., Xu, X., Chen, Z., Duan, J., Hashimoto, K., Yang, L., Liu, C., and Yang, C. (2020). Nervous system involvement after infection with COVID-19 and other coronaviruses. Brain Behav. Immun. 87: 18-22.

Wucherpfennig, K.W., Catz, I., Hausmann, S., Strominger, J.L., Steinman, L., and Warren, K.G. (1997). Recognition of the immunodominant myelin basic protein peptide by autoantibodies and HLA-DR2-restricted T cell clones from multiple sclerosis patients. Identity of key contact residues in the B-cell and T-cell epitopes. J. Clin. Invest. 100: 1114-1122.

Ye, M., Ren, Y., and Lv, T. (2020). Encephalitis as a clinical manifestation of COVID-19. Brain Behav. Immun. 88: 945-946.

Yeh, E.A., Collins, A., Cohen, M.E., Duffner, P.K., and Faden, H. (2004). Detection of coronavirus in the central nervous system of a child with acute disseminated encephalomyelitis. Pediatrics 113: e73-76.

Zabalza, A., Cárdenas-Robledo, S., Tagliani, P., Arrambide, G., OteroRomero, S., Carbonell-Mirabent, P., Rodriguez-Barranco, M., 
Rodríguez-Acevedo, B., Restrepo Vera, J.L., Resina-Salles, M., et al. (2021). COVID-19 in multiple sclerosis patients: susceptibility, severity risk factors and serological response. Eur. J. Neurol. 28: 3384-3395.

Zanin, L., Saraceno, G., Panciani, P.P., Renisi, G., Signorini, L., Migliorati, K., and Fontanella, M.M. (2020). SARS-CoV-2 can induce brain and spine demyelinating lesions. Acta Neurochir. 162: 1491-1494.

Zhang, T., Hirsh, E., Zandieh, S., and Rodricks, M.B. (2021). COVID19-associated acute multi-infarct encephalopathy in an asymptomatic CADASIL patient. Neurocrit. Care 34: 1099-1102.

Zhang, Y., Xiao, M., Zhang, S., Xia, P., Cao, W., Jiang, W., Chen, H., Ding, X., Zhao, H., Zhang, H., et al. (2020). Coagulopathy and antiphospholipid antibodies in patients with covid-19. N. Engl. J. Med. 382: e38.
Zhu, N., Zhang, D., Wang, W., Li, X., Yang, B., Song, J., Zhao, X., Huang, B., Shi, W., Lu, R., et al. (2020). A novel coronavirus from patients with pneumonia in China, 2019. N. Engl. J. Med. 382: 727-733.

Zlateva, K.T. and Van Ranst, M. (2004). Detection of subgroup B respiratory syncytial virus in the cerebrospinal fluid of a patient with respiratory syncytial virus pneumonia. Pediatr. Infect. Dis. J. 23: 1065-1066.

Zoghi, A., Ramezani, M., Roozbeh, M., Darazam, I.A., and Sahraian, M.A. (2020). A case of possible atypical demyelinating event of the central nervous system following COVID-19. Mult. Scler. Relat. Disord. 44: 102324.

Zulfiqar, A.A., Lorenzo-Villalba, N., Hassler, P., and Andrès, E. (2020). Immune thrombocytopenic purpura in a patient with covid-19. N. Engl. J. Med. 382: e43. 